\title{
QUEEN'S
UNIVERSITY
BELFAST
}

\section{A Review of the Radiocarbon Dates for the Afanasyevo Culture (Central Asia): Shifting Towards the "Shorter" Chronology}

Poliakov, A. V., Svyatko, S. V., \& Stepanova, N. F. (2019). A Review of the Radiocarbon Dates for the Afanasyevo Culture (Central Asia): Shifting Towards the "Shorter" Chronology. Radiocarbon, 61(1), 243-263. https://doi.org/10.1017/RDC.2018.70

\section{Published in:}

Radiocarbon

\section{Document Version:}

Peer reviewed version

Queen's University Belfast - Research Portal:

Link to publication record in Queen's University Belfast Research Portal

Publisher rights

(C) 2018 by the Arizona Board of Regents on behalf of the University of Arizona.

This work is made available online in accordance with the publisher's policies. Please refer to any applicable terms of use of the publisher.

\section{General rights}

Copyright for the publications made accessible via the Queen's University Belfast Research Portal is retained by the author(s) and / or other copyright owners and it is a condition of accessing these publications that users recognise and abide by the legal requirements associated with these rights.

Take down policy

The Research Portal is Queen's institutional repository that provides access to Queen's research output. Every effort has been made to ensure that content in the Research Portal does not infringe any person's rights, or applicable UK laws. If you discover content in the Research Portal that you believe breaches copyright or violates any law, please contact openaccess@qub.ac.uk. 


\title{
A review of the radiocarbon dates for the Afanasyevo Culture (Central Asia): Shifting to- wards the "shorter" chronology
}

\begin{abstract}
This article provides a summary and in-depth analysis of all existing radiocarbon dates for the Afanasyevo Culture of the Paleometal period. The previous "long" chronology of the Culture was widely criticised and contradicted many archaeological observations. The exceedingly wide ranges of the liquid scintillation counting (LSC) dates from bone samples produced in several laboratories and the systematically older ages for the wood/charcoal samples finally reveal the shortcomings of the conventional "long" chronology. From accelerator mass spectrometry (AMS), the Afanasyevo burials of the Altai are dated to the 31st-29th c. BC, whereas those of the Middle Yenisei Region to the 29th-25th c. BC, which confirms the relatively earlier age of the Altai monuments. The "short" chronology removes the incompatibility of deriving the Afanasyevo Culture from the Yamnaya Culture, which previously appeared "younger" than the Afanasyevo, and also contradictions with the archaeological data. It also explains the small number of sites, the small size of the cemeteries and the lack of the internal periodization. We can now clearly move, from the earlier understanding that the Afanasyevo chronology is too broad, towards a different perception. The new AMS dates only represent a "core" for the Afanasyevo chronology, which cannot be narrowed down, but could be slightly expanded over time.
\end{abstract}

\section{Keywords}

Afanasyevo Culture, radiocarbon chronology, old wood effect, Paleometal period, Minusinsk Basin, Altai

\section{Introduction}

\section{The Afanasyevo Culture and the sites}

This study aims to systematise and analyse all radiocarbon $\left({ }^{14} \mathrm{C}\right)$ dates available so far for one of the most important archaeological cultures of the Central Asian Paleometal period - the Afanasyevo. The problem of the attribution of the Afanasyevo Culture to a particular archaeological period has long been a complicated and topical issue. The Culture has been attributed by various scholars to the Eneolithic (Gryaznov 1999; Vadetskaya 1986) or Early Bronze Age periods (Kuzminyh 1993; Molodin 2002; Pogozheva et al. 2006). To avoid ambiguity, we will be using the term "Paleometal period". Importantly, this culture is associated with the introduction of western/Central Asian domesticated herd animals (sheep, goat, cattle, probably horse) into East Asia, as well as skilled metallurgists who had an advanced tradition of construction of kurgans (tumuli). Afanasyevo people were migrants in Southern Siberia, who introduced a food producing economy into the local environment of ceramic-using hunter-gatherers (Anthony 2007). Modern anthropological and DNA data support the hypothesis of the distant Western ancestry of the Afanasyevo population (Khokhlov et al. 2016; Rasmussen et al. 2015). The majority of the Afanasyevo sites have been discovered in the Altai-Sayan mountain region, which comprises a system of ridges of various elevations, river valleys, plateaus and intermontane basins with continental climate (Fig. 1). There have been 35 cemeteries and 12 settlements discovered in the Middle Yenisei River area, and 77 cemeteries, ca. 40 settlements, a ritual site, a mine and traces of human activity identified in four caves - in the Altai Mountains (Vadetskaya et al. 2014). The distance between the Altai and the Middle Yenisei Region groups of sites is at least 300-500 km, and the distance between the closest sites within those regions is 0.5 to several kilometres, which demonstrates their strong concentration in certain valleys and basins. Individual Afanasyevo type sites and artefacts have also been found in other areas of Central Asia - Northwest Mongolia, Northwest China, and the Zeravshan River Valley (Molodin and Alkin, 2012; Avanesova 2012).

In the Altai, Afanasyevo sites are mainly located in the valleys of the Katun River and its tributaries, at an altitude of 450 to 4000 m.a.s.l. With the altitude increasing from north-west to 
south-east, the territory is divided into low-, mid- and high-mountain zones. Apart from highlands, the landscape encompasses intermountain basins. The Altai has an extensive hydrological system, with the largest river being the Katun and its main tributaries the Koksa, Argut, Chuya, Kadrin, Ursul and Sema. The nature of vegetation in the region is determined by topography and altitude - the mountain-steppe, mountain-taiga and alpine high-altitude zones are clearly defined in the region. Different areas of the Altai Mountains have distinctive zonal characteristics, related to climatic differences.

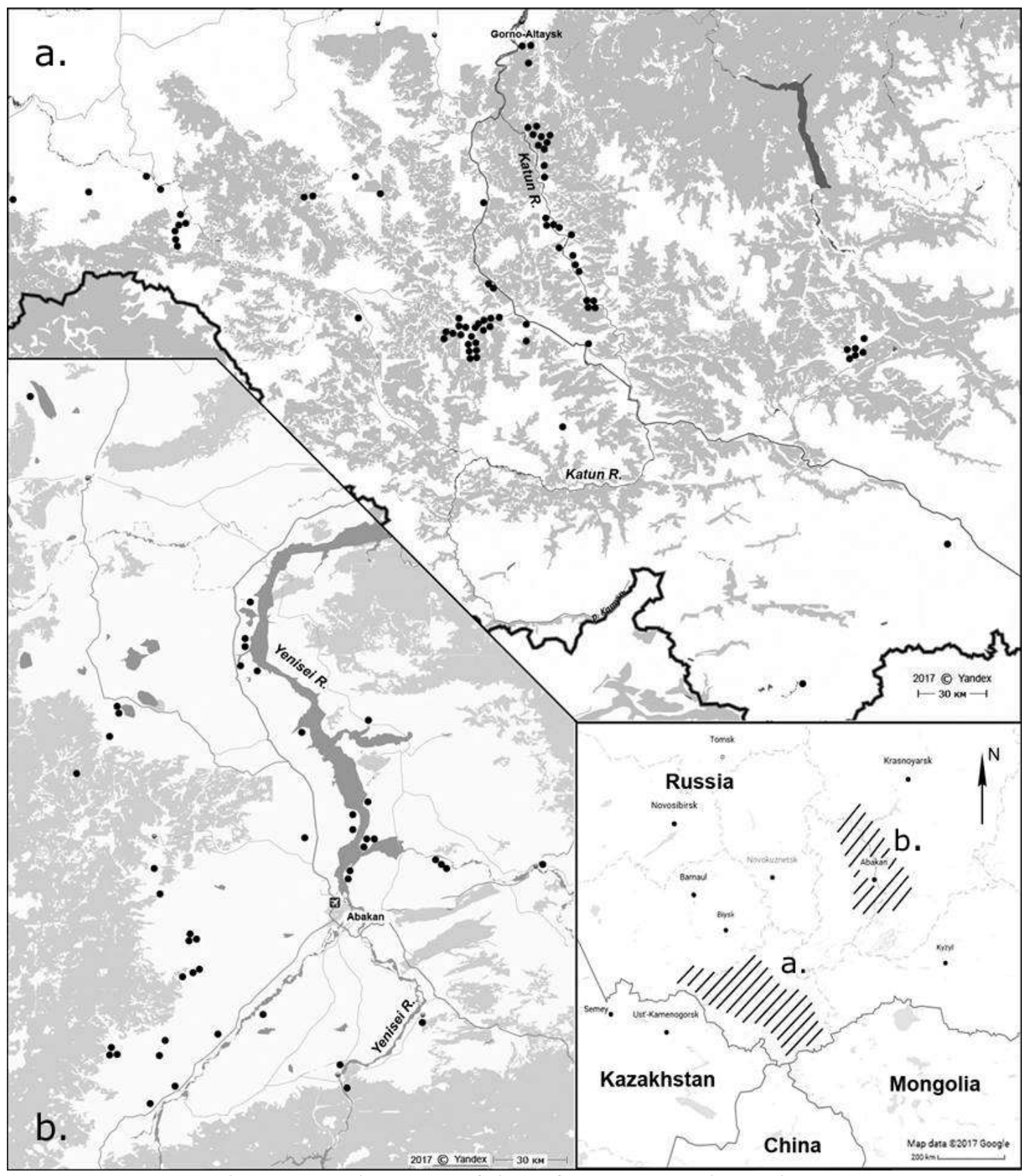

Fig. 1. Location map of the Afanasyevo Culture sites in Altai (a) and the Minusinsk Basin (b)

In the Middle Yenisei Region, Afanasyevo sites are located in the Minusinsk intermountain basins, which stretch along the middle reaches of the Yenisei River. This is a relatively small (ca. $350 \times 100 \mathrm{~km}$ ) area of rolling steppe, surrounded on all sides by mountains - the Eastern and Western Sayan and Kuznetsky Alatau. The altitude of the basins is 300-400 m.a.s.1. They are comprised of steppe and forest steppe, surrounded by taiga covered mountains. Such proximity of different climatic zones is an important feature of this territory. The Minusinsk depression is very 
rich in aquatic resources. From south to north, it is cut by the Yenisei River with its multiple tributaries, the largest being Abakan and Tuba. The area encompasses hundreds of lakes. Such a wealth of natural resources allowed prehistoric people to use variable economic models.

\section{Overview of the absolute dating of the Afanasyevo Culture}

A specific feature of the Afanasyevo Culture is its very broad date range, running from the end of $4^{\text {th }}$ to the beginning of $2^{\text {nd }}$ mil. $\mathrm{BC}$ based on both relative cultural analogies and radiocarbon dates (see Tsyb 1984, Molodin 2002).

Kiselev (1938) was the first scientist to raise the issue of the absolute chronology of the Afanasyevo sites. Based on a series of objects ("censers, cylinders, beaters"), he suggested that Afanasyevo cemeteries were synchronous with "Yamnaya-Catacombnaya burials" and dated them to the $3^{\text {rd }}$ - beginning of the $2^{\text {nd }}$ mil. BC. This approach was followed by researchers until the appearance of the first radiocarbon dates. In the 1970s, M.P. Gryaznov (1999) admitted that "we do not yet have data for direct dating of the monuments of the Afanasyevo Culture in the Minusinsk steppes. Their mentioned affinity with the monuments of the Yamnaya ("Pit Grave") Culture only allows suggesting their synchroneity to Yamnaya, which is usually dated to the second half of the $3^{\text {rd }}$ mil. BC. Hence, the Afanasyevo Culture is accepted to date to the same time. If the date of the Yamnaya Culture changes, the date of the Afanasyevo Culture will also be needed to be changed, respectively".

The issues of dating of the Afanasyevo Culture have been discussed by many researchers. M.D. Hlobystina (1975) dated the Afanasyevo Culture of Altai from the second half of the $3^{\text {rd }}$ mil. $\mathrm{BC}$ based on relative analogies with the the material culture and funeral rite of the Yamnaya Culture. On the basis of the relative similarities with the monuments of the Yamnaya cultural-historical region in Eastern Europe, the Kelteminar Culture of Khwarezm and other cultures, and radiocarbon dates from five burials, Tsyb (1984) dated the Afanasyevo monuments of Altai to the end of the $4^{\text {th }}$ - first quarter of $2^{\text {nd }}$ mil. BC. Savinov (1994), exploring the materials from the burials of the most southerly Afanasyevo burial in the Altai Mountains - Bertek-33 - noted that, at that stage of the study of the culture, the most likely date for it would be the $3^{\text {rd }}$ - beginning of the $2^{\text {nd }}$ mil. BC. Pogozheva (2006) suggested that the Afanasyevo population appeared in the Altai in the first half of the $3^{\text {rd }}$ mil. $\mathrm{BC}$ and that it would be difficult to give a more precise date. According to Molodin (2002), the general trends in the development of cultures of Eurasia, outlined in his summary work, suggested a chronological framework for the Afanasyevo Culture which ran from the $4^{\text {th }}$ to the beginning of the $2^{\text {nd }}$ mil. BC.

The radiocarbon stage in the study of the Afanasyevo Culture began in the 1960s (Sementsov et al. 1969). First, individual sites were dated, and later attempts were made to determine the chronology of the Culture in general. Vadetskaya (1981) was the first scholar to propose the dating of the Afanasyevo Culture based solely on (non-calibrated) radiocarbon dates. The same year, the first ${ }^{14} \mathrm{C}$ dates for Altai sites were published, which were used as a basis for the absolute dating (Kiryushin et al. 1981). Analyses were carried out in the laboratories of the Siberian Branch of the Russian Academy of Sciences (SB RAS; Novosibirsk, lab. code SOAN), the Institute for the History of Material Culture of the Russian Academy of Sciences (IHMC RAS; Saint-Petersburg, lab. code Le) and the German Academy of Sciences (Berlin, lab. code Bln) using conventional beta counting methods (LSC and GPC). However, only non-calibrated dates were used at that time, which seriously affected the conclusions.

The constant gradual increase of the number of ${ }^{14} \mathrm{C}$ dates lead to the necessity of revisiting the data at a new level. To date, 102 radiocarbon dates have been obtained for the Afanasyevo Culture - 39 for the Middle Yenisei Region and 63 for Altai (including Mongolian Altai).

\section{The problem of the "wide" chronology of the Afanasyevo Culture}

For a long time, the lengthy existence of the Afanasyevo Culture was not questioned for a number of reasons, partly because of the lack of known archaeological sites of cultures preceding 
and succeeding Afanasyevo in the Altai Mountains. It was even suggested that Afanasyevo was an ultra-conervative culture and that the population survived little changed until the Early Iron Age (Abdulganeev et al. 1982), which was partly "supported" by the ${ }^{14} \mathrm{C}$ dates (Kiryushin et al. 1981).

In the past two decades, special attention has been given to the Afanasyevo Culture. As a result, the contradictions between the results of radiocarbon dating and archaeological data have become particularly apparent. According to ${ }^{14} \mathrm{C}$ analysis, the chronological span of the Afanasyevo Culture can be identified as $38^{\text {th }}-25^{\text {th }} \mathrm{c}$. BC for the Altai Mountains, and $33^{\text {rd }}-25^{\text {th }} \mathrm{c}$. BC for the Middle Yenisei Region (Svyatko \& Polyakov 2009, Polyakov 2010). However, with growing data from ${ }^{14} \mathrm{C}$ dating and material culture, it has become obvious that the proposed existence of the Afanasyevo Culture for 1400-1500 years is very extended; there is no archaeological evidence for the Afanasyevo population residing there for such a long time (Stepanova 2009, 2012; Vadetskaya et al. 2014). A chronological period of almost 1500 years must inevitably split into stages, traceable in the development of all elements of the culture, including the funeral rite. However, despite almost a century of the study of Afanasyevo antiquities, such a development has not been established and described.

Another important argument in favour of the shorter existence of the culture is the scarcity of archaeological sites. As a rule, the long-existing archaeological cultures are characterised by several times greater number of burial complexes and people buried, such as has been recorded for the Yamnaya Culture (Merpert 1974; Fisenko 1970; Kovaleva 1984; Yarovoy 1985, 1990; Dergachev 1986; Shaposhnikova 1986; Morgunova \& Kravtsov 1994). For example, for the Andronovo Culture of the Altai, 62 funerary complexes are known, containing more than 700 burials dating to the $19^{\text {th }}$ and $18^{\text {th }}$ c. BC (i.e. for only two centuries in total; Kiryushin \& Papin 2010; Kiryushin et al.2015). Quite illustrative are the materials of the Karasuk Culture, dated to the $13^{\text {th }}$ $9^{\text {th }}$ c. BC (i.e. 500 years of existence), yet already ca. 3000 burials have been investigated to date, with this only being a few per cent of the total number of burials known (Polyakov 2006). At the same time, to date only about 600 Afanasyevo burials in total have been excavated - more than 300 in the Middle Yenisei region, more than 200 in the Altai and ca. ten in Mongolia). The territory of the Altai Mountains and Minusinsk Basin has already been sufficiently explored archaeologically, and therefore there is no reason to expect a significant increase in the number of new monuments to be discovered. Taking into account the Afanasyevo cemeteries which have not been excavated, as well as the fact that some burials have not been discovered yet, the number of monuments is still insufficient to assume the long existence of the culture implied by the ${ }^{14} \mathrm{C}$ chronologies. In this regard, the data on the number of the deceased people is of a particular interest. In the Middle Yenisei Region, the average number of kurgans within a cemetery usually does not exceed ten, and the cemeteries themselves are extremely rare. The largest number of people buried within one site is 66. In the Altai, the number of kurgans within a cemetery is often more than 40 (Perviy Mezhelik-1, Saldjar-1), but there are also sites containing fewer than ten kurgans (Elo-1 and 2, Bertek-33 and others). Judging by the almost completely investigated major burial ground of Saldjar-1, the number of people buried within is around 40 (only 13 of them adults, the rest are children and teenagers; Vadetskaya et al. 2014). Even if we assume that each cemetery contains 13-15 adults, this is still much less than in sites of other archaeological cultures. Therefore, most Afanasyevo cemeteries in both regions functioned for short periods. It is also worth noting that there are several times more Scythian sites in the Altai than Afanasyevo, despite the chronological span of the former is limited to 200-300 years (Marsadolov 1985; Surazakov1989; Kiryushin \& Stepanova 2004; Slyusarenko 2010 and others). Similar examples can be highlighted for other Paleometal to Early Iron Age archaeological cultures of the Sayan and Altai Mountains.

The hypothesis of the synchronous and short-term functioning of many of the Afanasyevo sites is also supported by the analysis of pottery. The characteristics of manufacturing technology and ornamentation of the Afanasyevo ceramics from the Altai suggest that many of the items were manufactured in a short period of time by several groups of potters (at different sites). Two to four vessels, obviously made by same group of craftsmen within a few years, can be found in various 
sites, and this allows synchronizing the sites. Comparison of such groups of vessels indicates that most cemeteries and settlements were close to each other chronologically (Stepanova 2009). The analysis of manufacturing technologies shows that Afanasyevo potters adapted to new environments and unfamiliar territories. The materials from the majority of sites indicate rapid decline of the introduced, foreign traditions and the emergence of new ones, more specific to mountainous areas. This has been recorded for both the source raw materials and artificially introduced mineral impurities in the fabric of the clay (Stepanova 2008, 2010c, 2015).

Another reason for the refinement of the chronology of the Afanasyevo Culture is that its

${ }^{14} \mathrm{C}$ dates are relatively earlier than those of the Yamnaya Culture, which does not agree with modern archaeological theories (Polyakov 2010). There are no doubts among researchers that the formation of the Afanasyevo Culture was a result of a major migration wave from the west (e.g. Mallory 1989; Mallory and Mair 2000; Kuzmina 2007; Anthony 2007). This has also been confirmed by the latest aDNA tests that directly link the Yamnaya Culture and the Afanasyevo Culture (Allentoft et al. 2015). If we accept the fact of formation of the Afanasyevo Culture by the $38^{\text {th }} \mathrm{c}$. $\mathrm{BC}$, it will also need to be accepted that all known similarities have been borrowed by the Yamnaya Culture from the supposedly more ancient Afanasyevo population, which has no archaeological evidence. The trajectory of all major innovations during this period would be assumed to have been directed from East to West, and not vice versa.

To sum up, it should be noted that there is no other archaeological culture, which could be characterised by such a relatively small number of funerary complexes and such wide chronological boundaries. Either there was extreme paucity of the Afanasyevo population in the Altai Mountains or there was an extended chronology of this culture. The revision of the dating of the Afanasyevo Culture has become highly topical. This study aims at resolving of this contradiction.

\section{${ }^{14} \mathrm{C}$ Dating of the Afanasyevo Sites}

\section{First data}

The Afanasyevo Culture was one of the first in Russia to be radiocarbon dated. In the late 1950 s, one of the first ${ }^{14} \mathrm{C}$ laboratories in the country and in the world was organized in the Leningrad Branch of the Institute of Archaeology of the USSR (presently IHMC RAS; Zaitseva 2007). In this same period, the major Krasnoyarsk expedition led by M.P. Gryaznov started its work in the Middle Yenisei River region. At his disposal were new materials from the entire stratigraphic column of the archaeological cultures of the region. However, at the initial stage, due to laboratory requirements, only charcoal and, later, wood samples could be analysed, which greatly limited the number of archaeological sites for which a ${ }^{14} \mathrm{C}$ age could be determined. Bone samples started to be dated routinely in the laboratory of IHMC RAS only in mid- 1990s, and, as such, the overwhelming number of the Afanasyevo dates are still those made on charcoal and wood, especially for the Minusinsk Basin sites, where ${ }^{14} \mathrm{C}$ dating was initiated earlier than in Altai. The ${ }^{14} \mathrm{C}$ dating of the Altai sites was not started until 1970s (Ermolova \& Markov 1983; Orlova 1995).

Among the Paleometal cultures of the Middle Yenisei Region, the wooden structures are widely present only in the sites of the Afanasyevo and later Andronovo (Fyodorovo) Cultures. It is with them that the radiocarbon research into archaeological sites of Siberia began (Sementsov et al. 1969). The very first ${ }^{14} \mathrm{C}$ dates for both cultures appeared extremely scattered and this drew a lot of skepticism towards them (Svyatko at al. 2009; Polyakov \& Svyatko 2009). This has led to persistent distrust of radiocarbon dating among Soviet and Russian researchers for several decades (see Molodin 2002).

The entire initial period of radiocarbon research into the Afanasyevo Culture can be characterized by a large number of issues, which question the attribution of a number of obtained dates. The major issue is concerned with the sampling and lack of understanding of the very principles of the method. Often "charcoals" from the grave filling were dated, however, their connection with the burial itself was not obvious, as it happened, for example, with kurgan 2 of the Maliye Kopeny 
II cemetery (Le-455; Vadetskaya 2012). The situation is similar for the Vostochnoye kurgan, where the charcoal sample (Le-1316) was taken from the "little fireplace", located within the mound but not directly associated with the graves, and not containing any artifacts (Vadetskaya et al. 2014), and for a number of sites in the Altai, where charcoal samples were taken from grave filling or ceiling.

Another problem for the Middle Yenisei Region is later intrusions, in particular - intrusive burials of the succeeding Okunevo Culture (Maksimenkov 1965). This is a widespread phenomenon, which is not always possible to identify reliably - at the later stages of the Okunevo Culture, the burials did not contain grave goods. In total, $95 \%$ of the Afanasyevo graves were subject to later intrusions. As a result, there is always a chance that the individual found in the grave without directly related goods is a later burial. In addition, the wooden ceiling of the grave, or some of its $\operatorname{logs}$, could be replaced. In this case, the obtained ${ }^{14} \mathrm{C}$ date will define not the time of construction of the Afanasyevo mound, but the time of the intrusion of the Okunevo burial. Perhaps this was the case with grave 3 of kurgan 4 of the Chernovaya VI cemetery. This mound contained the intrusive cist №5 with Okunevo tools, and it cannot be excluded that the central Afanasyevo graves (№3 and №4) may also be intrusive Okunevo burials (Vadetskaya 2010). Therefore, the date received from the "wood sample from the fallen ceiling of the pit" (Le-532) raises certain doubts as to its immediate connection with the very moment of construction of the Afanasyevo kurgan. Moreover, by modern views, the date itself, $3700 \pm 80$ BP (2346-1883 cal BC), rather corresponds with the timing of the Okunevo Culture (Svyatko at al. 2009; Polyakov \& Svyatko 2009).

Taking into consideration the aforementioned problems, the most controversial dates for which attribution to the Afanasyevo Culture is doubtful (Le-455; Le-532; Le-1316) were excluded from further statistical analysis.

\section{AMS dates}

A new stage in the study of the radiocarbon chronology of Southern Siberia commenced with the appearance of the first accelerator mass spectrometry (AMS) dates. The largest series of 88 human bone samples was analyzed in the laboratory of the ${ }^{14} \mathrm{CHRONO}$ Centre for Climate, the Environment, and Chronology (Queen's University Belfast, UK) in order to obtain a fully coherent chronological sequence of the Paleometal archaeological cultures of the Middle Yenisei. All ${ }^{14} \mathrm{C}$ dates available at the time for the region were assembled and a new chronological scale, fully based on the results of the radiocarbon analysis, was developed (Svyatko at al. 2009; Polyakov \& Svyatko 2009). Only five new Afanasyevo ${ }^{14} \mathrm{C}$ dates for the Middle Yenisei sites of Afanasieva Gora and Karasuk III were introduced, and, being much less numerous than the ones obtained by conventional methods, they did not have a major influence on the overall perception of the timing of the culture (Polyakov 2010).

Later, along with the increasing number of beta counting dates, another small series of AMS dates was made in the Oxford Radiocarbon Accelerator Unit (University of Oxford, UK) as a part of a DNA study of ancient Siberian populations by the Centre for GeoGenetics of the Natural History Museum of Denmark (University of Copenhagen; Rasmussen at al. 2015). However, the number of AMS dates was still rather small, and they were only produced for the Middle Yenisei sites.

The turning point, which prompted the revision of the chronology of the Afanasyevo Culture, was a series of new AMS ${ }^{14} \mathrm{C}$ dates from human and animal bones from the Afanasyevo sites of Altai also produced in the ${ }^{14} \mathrm{CHRONO}$ Centre (Svyatko et al. 2017b). These included the repeated analysis of burials previously dated by the liquid scintillation counting (LSC) method. Subsequently, one more date from a wood sample was obtained in the same laboratory. The discrepancies observed from these tests required a new interpretation of the results and prompted the present study. 


\section{Methods and modern research}

Two methods have been used to radiocarbon date the archaeological materials of the Afanasyevo Culture.

For decades, beta counting remained the only approach. It involves measuring the radioactive decay of individual carbon atoms and requires a long counting time to achieve accuracy of the date. It also requires a large sample size - 500-700 g of bone, and 200-400 g of wood or charcoal.

The alternative accelerator mass spectrometry method, developed in the late 1970s, involves a direct counting of the number of ${ }^{14} \mathrm{C}$ and ${ }^{12} \mathrm{C}$ atoms in a sample, rather than measuring its activity. As a result, AMS is much faster - an accuracy of $1 \%$ can be achieved in several minutes, and it requires a far smaller size of samples, from a few milligrams to a gram, depending on the sample type.

Notably, the recent radiocarbon intercomparison exercises (VIRI) showed general agreement in the results when comparing radiometric and AMS laboratories both for bone (Scott et al. 2010a) and wood/charcoal samples (Scott et al. 2010b), despite the early radiocarbon intercomparison exercises showing that LSC laboratories needed a larger lab error multiplier (Scott et al. 1992).

From the total number of ca. 100 radiocarbon dates, presently available for the Afanasyevo Culture, 76 were produced using beta counting (LSC и GPC), and 25 - using AMS.

Presently, major attention has also been given to the influence of freshwater reservoir effects on ${ }^{14} \mathrm{C}$ dates of various types of archaeological materials, including bones of humans and some animals (e.g. fish). The freshwater reservoir effects appear as older ${ }^{14} \mathrm{C}$ dates of organisms with a diet that included "old" carbon from freshwater sources (Lanting \& van der Plicht 1998). The studies have been carried out in several regions of Southern Siberia, including the Minusinsk Basin (Svyatko et al. 2017a) and the Altai (Svyatko et al. 2017b). This research revealed an interesting pattern. Modern fish showed freshwater reservoir offsets of $165 \pm 30$ to $757 \pm 31{ }^{14} \mathrm{C}$ years for the Minusinsk Basin $(n=4)$ and $578 \pm 36$ and $1097 \pm 40{ }^{14} \mathrm{C}$ years for Altai $(n=2)$. For archaeological samples, only six associated groups of samples (including human and herbivore bone, charcoal and wood) from the Afanasyevo, Okunevo, Karasuk and Tashtyk Cultures have been dated. Surprisingly, with the exception of one Tashtyk pair, these groups showed no clear evidence for a reservoir effect. From stable isotope analysis it is not clear whether humans were consuming any significant amounts of fish in the Altai; for the Minusinsk Basin stable isotopes are indicative of fish contributing to the diet (Svyatko et al. 2017c).

\section{Absolute Chronology}

\section{Altai burial sites and the "old wood effect"}

A new series of ${ }^{14} \mathrm{C}$ dates for the Afanasyevo sites from the Altai (Svyatko et al. 2017b) highlights the issue of credibility of a number of earlier dates. Comparison with the previous results demonstrates major discrepancies. For example, based on earlier ${ }^{14} \mathrm{C}$ dates from wood (Le-1607 and SOAN-6144), the cemetery of Kara-Koba-1 was considered to be one of the oldest Afanasyevo funeral monuments (Fig. 6 in Polyakov 2010). However, two new dates (UBA-22985 and UBA22986) obtained from human bones from the same grave and the kurgan beside are 600-700 years younger (Fig. 2). An additional AMS date from wood of the same grave (UBA-35116) is synchronous with the new human bone dates. Thus, based on AMS dating, this burial ground appears much more recent than previously thought.

A similar situation can be observed for another "oldest" cemetery of Elo-Bashi - the single date received from a wood fragment of enclosure 5 is also around $600{ }^{14} \mathrm{C}$ years older than that from human bones from enclosures 3 and 4 (Fig. 2). Two more cases should be brought up here, which have previously been mentioned, but have not been regarded as systematic phenomenon 
(Fig. 7 and 8 in Polyakov 2010). The first case is dates from Nizhniy Ayry-Tash kurgan 1 (SOAN5457 and SOAN-5458), where the wood sample turned out to be at least 250 years older than human bone. Two more dates obtained later from wood samples from this burial also came out 500-600 years older than the human bone (Soenov et al. 2012, Table 1, Fig. 2). The second case is the cemetery of Nizhniy Tyumechin-1. The dates measured on the wood sample from enclosure 7 (Le-1606) appeared 900 years older than those on human bone from enclosure 9 (SOAN-6025).

\section{Table 1. Summary of all existing ${ }^{14} \mathrm{C}$ dates for the Afanasyevo sites}

Note, that samples of the same type with similar provenance represent duplicates/triplicates from the same object. In all cases samples of wood are taken from the ceilings of the graves.

Data from: ${ }^{1}$ Sementsov et al. $1969 ;{ }^{2}$ Vadetskaya $1981 ;{ }^{3}$ Zaitseva \& van Geel 2004; ${ }^{4}$ Zaitseva et al. $2005 ;{ }^{5}$ Ermolova \& Markov 1983; ${ }^{6}$ Svyatko et al. 2009; ${ }^{7}$ Polyakov 2010; ${ }^{8}$ Görsdorf et al. 1998a; ${ }^{9}$ Görsdorf 2002; ${ }^{10}$ Görsdorf et al. $2004 ;{ }^{11}$ Stepanova 2009; ${ }^{12}$ Orlova 1995; ${ }^{13}$ Vdovina 2004; ${ }^{14}$ Grushin 2009; ${ }^{15}$ Kiryushin et al. 2009; ${ }^{16}$ Derevyanko \& Molodin 1994; ${ }^{17}$ Orlova 1994; ${ }^{18}$ Bazhenov et al. 2002; ${ }^{19}$ Kovalev et al. 2008; ${ }^{20}$ Bokovenko \& Legran $2010 ;{ }^{21}$ Rasmussen at al. 2015; ${ }^{22}$ Svyatko et al. 2017b; ${ }^{23}$ Soenov \& Trifanova $2010 ;{ }^{24}$ present study; ${ }^{25}$ Soenov et al. 2012

The ${ }^{14} \mathrm{C}$ ages were calibrated using the OxCal 4.3.2 program (Bronk Ramsey 2009) and the IntCal13 calibration curve (Reimer et al. 2013).

\begin{tabular}{|c|c|c|c|c|}
\hline Lab ID & Sample type & Provenance & ${ }^{14} \mathrm{C} \mathrm{BP}$ & $\begin{array}{c}\text { Cal BC } \\
(2 \sigma) \\
\end{array}$ \\
\hline \multicolumn{5}{|c|}{ Middle Yenisei sites (39 dates) } \\
\hline OxA-31221 21 & human tooth & Afanasieva Gora, grave 15 & $4186 \pm 27$ & $2887-2677$ \\
\hline OxA-31568 21 & human tooth & Afanasieva Gora, grave 15 & $4224 \pm 36$ & $2909-2679$ \\
\hline OxA-31222 21 & human tooth & Afanasieva Gora, grave 17 & $4040 \pm 45$ & $2851-2468$ \\
\hline UB-7489 & human bone & Afanasieva Gora, grave 25 & $4077 \pm 39$ & $2861-2488$ \\
\hline UBA- $7903^{6}$ & human bone & Afanasieva Gora, grave 25 & $4037 \pm 31$ & $2832-2473$ \\
\hline UBA- $8772^{6}$ & human bone & Afanasieva Gora, grave 27 & $4092 \pm 27$ & $2859-2501$ \\
\hline Le- $532^{1}$ & wood & Chernovaya VI, kurgan 4 , grave 3 & $3700 \pm 80$ & $2346-1883$ \\
\hline Le- $8912^{7}$ & wood & Itkol II, kurgan 23, grave 1 & $4170 \pm 35$ & $2886-2631$ \\
\hline Le- $8913^{7}$ & human bone & Itkol II, kurgan 23, grave 1 & $4270 \pm 200$ & $3505-2342$ \\
\hline Le- $9410^{23}$ & wood & Itkol II, kurgan 24, grave 1 & $4000 \pm 30$ & $2577-2468$ \\
\hline Le-11433 24 & wood & Itkol II, kurgan 25 , grave 1 & $4240 \pm 50$ & $3002-2635$ \\
\hline Le- $8517^{6}$ & wood & Itkol II, kurgan 27 , grave 1 & $4170 \pm 30$ & $2882-2635$ \\
\hline UBA- $8773^{6}$ & human bone & Karasuk III, enclosure 1, grave 2, skeleton 2 & $3996 \pm 26$ & $2573-2469$ \\
\hline UBA- $8774^{6}$ & human bone & Karasuk III, enclosure 1 , grave 3 , skeleton 1 & $4148 \pm 26$ & $2875-2630$ \\
\hline Le- $930^{2}$ & wood & Krasniy Yar I, kurgan 7 & $4080 \pm 40$ & $2863-2489$ \\
\hline Le- $931^{2}$ & wood & Krasniy Yar I, kurgan 9 & $4170 \pm 50$ & $2891-2601$ \\
\hline Le- $1067^{2,3}$ & wood & Krasniy Yar I, kurgan 12 & $4240 \pm 60$ & $3011-2629$ \\
\hline Le- $1068^{2,3}$ & wood & Krasniy Yar I, kurgan 15 & $4160 \pm 40$ & $2882-2623$ \\
\hline Le- $1611^{4,5}$ & wood/charcoal & Letnik VI, enclosure 13 & $4250 \pm 40$ & $2926-2679$ \\
\hline Le- $1612^{3}$ & charcoal & Letnik VI, enclosure 14 & $4410 \pm 50$ & $3331-2909$ \\
\hline Le- $2115^{5}$ & wood/charcoal & Letnik VI, enclosure 14 & $4380 \pm 50$ & $3322-2895$ \\
\hline Le- $2116^{5}$ & wood/charcoal & Letnik VI, enclosure 14 & $4410 \pm 50$ & 3331-2909 \\
\hline Le-2094 & wood/charcoal & Malinoviy Log, enclosure 1, grave 1 (closure) & $4770 \pm 60$ & $3653-3376$ \\
\hline Le- $2091^{5}$ & wood/charcoal & Malinoviy Log, enclosure 4 , grave 1 (closure) & $4780 \pm 50$ & $3655-3377$ \\
\hline Le- $2092^{5}$ & wood/charcoal & Malinoviy Log, enclosure 4, grave 1 (closure) & $4790 \pm 50$ & $3659-3379$ \\
\hline Le- $2093^{5}$ & wood/charcoal & Malinoviy Log, enclosure 4, grave 1 (closure) & $4820 \pm 50$ & $3706-3384$ \\
\hline Le- $455^{1}$ & charcoal & Maliye Kopeny II, kurgan 2 & $4440 \pm 150$ & $3627-2696$ \\
\hline Le- $6146^{20}$ & human bone & Numakhyr, kurgan 1 & $4160 \pm 90$ & $2915-2488$ \\
\hline Le- $10985^{24}$ & human bone & Numakhyr, kurgan 10 & $3780 \pm 140$ & $2618-1777$ \\
\hline Le- $11380^{24}$ & human bone & Numakhyr, kurgan 11 & $4170 \pm 150$ & $3322-2306$ \\
\hline Le- $694^{1}$ & wood & Sargov Ulus, grave 3 & $4270 \pm 60$ & $3084-2669$ \\
\hline $\mathrm{B} \ln -4764^{8}$ & wood & Sukhanikha, object 6 , stone circle & $4409 \pm 70$ & $3337-2904$ \\
\hline $\mathrm{B} \ln -4765^{8}$ & wood & Sukhanikha, object 6 , stone circle & $4259 \pm 36$ & $2927-2701$ \\
\hline $\mathrm{B} \ln -4766^{8}$ & wood & Sukhanikha, object 2 , grave 2 & $4205 \pm 44$ & $2904-2636$ \\
\hline
\end{tabular}




\begin{tabular}{|c|c|c|c|c|}
\hline $\mathrm{B} \ln -4767^{8}$ & wood & Sukhanikha, object 6 , grave 1 & $4253 \pm 36$ & 2923-2701 \\
\hline$B \ln -4769^{8}$ & wood & Sukhanikha, object 6 , grave 1 & $4022 \pm 40$ & $2834-2466$ \\
\hline $\mathrm{B} \ln -4919^{9}$ & wood & Sukhanikha, object 6 , grave 15 & $3936 \pm 35$ & $2566-2299$ \\
\hline $\mathrm{B} \ln -5280^{9,10}$ & wood & Sukhanikha II, funeral structure 19a, grave 1 & $4271 \pm 30$ & $2926-2778$ \\
\hline Le- $1316^{3}$ & charcoal & Vostochnoye, pit with charcoals within the kurgan & $3880 \pm 30$ & $2467-2236$ \\
\hline \multicolumn{5}{|c|}{ Altai Mountains sites (57 dates) } \\
\hline SOAN-2744 ${ }^{16}$ & soil substance & Denisova cave & $5200 \pm 30$ & $4048-3960$ \\
\hline SOAN-2734 $4^{16,17}$ & soil & Denisova cave & $4190 \pm 30$ & $2891-2671$ \\
\hline SOAN-2738 ${ }^{16,17}$ & soil & Denisova cave & $4315 \pm 30$ & $3014-2888$ \\
\hline SOAN-2739 16,17 & charcoal & Denisova cave & $4265 \pm 30$ & $2923-2765$ \\
\hline SOAN-2740 ${ }^{16,17}$ & soil & Denisova cave & $4225 \pm 30$ & $2907-2695$ \\
\hline SOAN-2742 $2^{16,17}$ & soil & Denisova cave & $4725 \pm 70$ & $3639-3370$ \\
\hline SOAN-2312 & charcoal & Kaminnaya cave & $4130 \pm 85$ & $2894-2488$ \\
\hline SOAN-2313 ${ }^{12}$ & charcoal & Kaminnaya cave & $4180 \pm 90$ & $3006-2488$ \\
\hline SOAN-2563 ${ }^{12}$ & charcoal & Kaminnaya cave & $4335 \pm 130$ & $3362-2622$ \\
\hline SOAN- $2844^{12}$ & charcoal & Kaminnaya cave & $5000 \pm 140$ & $4226-3384$ \\
\hline SOAN-1628 ${ }^{12}$ & wood & Kuyus (Kara-Tenesh), hearth & $4290 \pm 20$ & $2919-2886$ \\
\hline UBA-2298922 & bone, sheep & Maliy Dugan & $4209 \pm 34$ & $2901-2677$ \\
\hline UBA-22990 22 & bone, roe-deer & Maliy Dugan & $4197 \pm 36$ & $2896-2666$ \\
\hline \multicolumn{5}{|l|}{ cemeteries } \\
\hline UBA- $22988^{22}$ & human bone & Ayrydash 1, burial 15 & $4336 \pm 34$ & $3081-2892$ \\
\hline Le- $1610^{5}$ & wood & Elo-1, enclosure 2 & $4750 \pm 50$ & $3641-3376$ \\
\hline SOAN- $1521^{12}$ & wood & Elo-1, enclosure 2 & $4720 \pm 25$ & $3632-3377$ \\
\hline Le- $1609^{5}$ & wood & Elo-1, enclosure 4 & $4410 \pm 50$ & $3331-2909$ \\
\hline SOAN- $1685^{12}$ & wood & Elo-1, enclosure 4 & $4420 \pm 30$ & $3321-2921$ \\
\hline UBA-22983 22 & human bone & Elo-Bashi, burial 3 & $4322 \pm 37$ & $3078-2886$ \\
\hline UBA- $22984^{22}$ & human bone & Elo-Bashi, burial 4 & $4392 \pm 40$ & $3311-2905$ \\
\hline Le- $1608^{5}$ & wood & Elo-Bashi, burial 5 & $4920 \pm 50$ & $3895-3636$ \\
\hline UBA- $26406^{22}$ & human bone & Inskoy Dol, kurgan 9 & $4255 \pm 35$ & $2922-2704$ \\
\hline UBA-22985 $5^{22}$ & human bone & Kara-Koba 1, burial 1 & $4394 \pm 37$ & $3308-2907$ \\
\hline UBA- $22986^{22}$ & human bone & Kara-Koba 1, burial 3 & $4346 \pm 35$ & $3084-2896$ \\
\hline Le- $1607^{5}$ & wood & Kara-Koba-1, burial 3 & $5100 \pm 50$ & $3989-3775$ \\
\hline SOAN-6144 ${ }^{11}$ & wood & Kara-Koba-1, burial 3 & $4965 \pm 80$ & $3949-3640$ \\
\hline UBA-35116 $6^{24}$ & wood & Kara-Koba 1, burial 3 & $4331 \pm 31$ & $3022-2893$ \\
\hline SOAN-7924 25 & wood & Nizhniy Ayry-Tash, kurgan 1 & $4780 \pm 85$ & $3706-3369$ \\
\hline SOAN-7925 25 & wood & Nizhniy Ayry-Tash, kurgan 1 & $4840 \pm 95$ & $3911-3372$ \\
\hline SOAN-5458 ${ }^{13}$ & wood & Nizhniy Ayry-Tash, kurgan 1 & $4480 \pm 50$ & $3360-3013$ \\
\hline SOAN-5457 ${ }^{13}$ & human bone & Nizhniy Ayry-Tash, kurgan 1 & $4225 \pm 60$ & $2999-2601$ \\
\hline SOAN-5459 $9^{13}$ & human bone & Nizhniy Ayry-Tash, kurgan 2 & $4725 \pm 40$ & $3635-3375$ \\
\hline Le- $1606^{5}$ & wood & Nizhniy Tyumechin-1, burial 7 & $4860 \pm 60$ & $3781-3520$ \\
\hline SOAN-6025 $5^{11}$ & human bone & Nizhniy Tyumechin-1, burial 9 & $3960 \pm 80$ & $2849-2203$ \\
\hline UBA-22987 22 & human bone & Ozernoye 2, kurgan 1 & $4404 \pm 36$ & $3316-2911$ \\
\hline SOAN-6026 ${ }^{11}$ & human bone & Perviy Mezhelik-1, burial 10 & $4315 \pm 85$ & $3331-2672$ \\
\hline UBA-29308 ${ }^{22}$ & human bone & Perviy Mezhelik-1, burial 12 & $4389 \pm 33$ & $3097-2912$ \\
\hline UBA-29309 22 & animal bone & Perviy Mezhelik-1, burial 12 & $4473 \pm 35$ & $3341-3026$ \\
\hline UBA-29305 22 & human bone & Saldyar-1, burial 17 & $4344 \pm 41$ & $3089-2891$ \\
\hline UBA-29306 22 & human bone & Saldyar-1, burial 31 & $4462 \pm 34$ & $3339-3021$ \\
\hline UBA-2930722 & human bone & Saldyar-1, burial 36 & $4409 \pm 34$ & $3316-2915$ \\
\hline SOAN-6028 ${ }^{11}$ & human bone & Tarkhata-1, burial 8 & $3985 \pm 60$ & $2836-2296$ \\
\hline SOAN-6761 & human bone & Tytkesken VI, kurgan 95 & $4250 \pm 110$ & $3322-2496$ \\
\hline SOAN- $7474^{15}$ & human bone & Tytkesken VI, kurgan 95 & $4295 \pm 85$ & $3323-2629$ \\
\hline Le- $7805^{14}$ & bone & Tytkesken VI, kurgan 95 & $3900 \pm 80$ & $2580-2140$ \\
\hline SOAN-6027 $7^{11}$ & human bone & Ust-Teplaya, excavation 2, burial 7 & $3975 \pm 75$ & $2852-2211$ \\
\hline
\end{tabular}




\begin{tabular}{|c|c|c|c|c|}
\hline OxA-31219 $9^{21}$ & human tooth & Ust-Kuyum, grave 6 & $4423 \pm 29$ & $3322-2923$ \\
\hline OxA-31220 21 & human tooth & Ust-Kuyum, grave 6 & $4442 \pm 29$ & $3331-2935$ \\
\hline SOAN-3802 $2^{18}$ & wood & Vladimirovka & $4665 \pm 75$ & $3640-3122$ \\
\hline \multicolumn{5}{|c|}{ Kurota Type } \\
\hline Le- $8157^{15}$ & human bone & Bersyukta I, kurgan 1 & $4380 \pm 110$ & $3369-2699$ \\
\hline SOAN- $7475^{15}$ & human bone & Bersyukta I, kurgan 1 & $4020 \pm 95$ & $2873-2299$ \\
\hline Le- $8158^{15}$ & human bone & Bersyukta I, kurgan 2 & $4500 \pm 90$ & $3495-2917$ \\
\hline Le- $8159^{15}$ & human bone & Bersyukta II, kurgan 2 & $4100 \pm 100$ & $2908-2351$ \\
\hline Le- $8154^{15}$ & human bone & Choburak I, kurgan 1 & $4340 \pm 70$ & $3331-2777$ \\
\hline Le- $8155^{15}$ & human bone & Choburak I, kurgan 2 & $4090 \pm 100$ & $2903-2350$ \\
\hline Le- $8156^{15}$ & human bone & Choburak III, kurgan 1 & $3930 \pm 100$ & $2855-2137$ \\
\hline SOAN-7862 $2^{23}$ & human bone & Nizhnyaya Tarkhata II, kurgan 4 & $4275 \pm 85$ & $3265-2581$ \\
\hline \multicolumn{5}{|c|}{ Mongolian sites (6 dates) } \\
\hline Le- $7219^{19}$ & human bone & Kurgak Govi-1 & $4180 \pm 100$ & $3050-2459$ \\
\hline Le- $7289^{19}$ & wood/charcoal & Kurgak Govi-1 & $4110 \pm 25$ & $2862-2577$ \\
\hline Le- $7290^{19}$ & wood/charcoal & Kurgak Govi-1 & $4025 \pm 50$ & $2856-2460$ \\
\hline Le-7291 ${ }^{19}$ & wood/charcoal & Kurgak Govi-1 & $4140 \pm 35$ & $2875-2601$ \\
\hline Le- $7292^{19}$ & wood/charcoal & Kurgak Govi-1 & $4130 \pm 40$ & $2873-2581$ \\
\hline Le- $7293^{19}$ & wood & Kurgak Govi-1 & $4085 \pm 30$ & $2859-2497$ \\
\hline
\end{tabular}




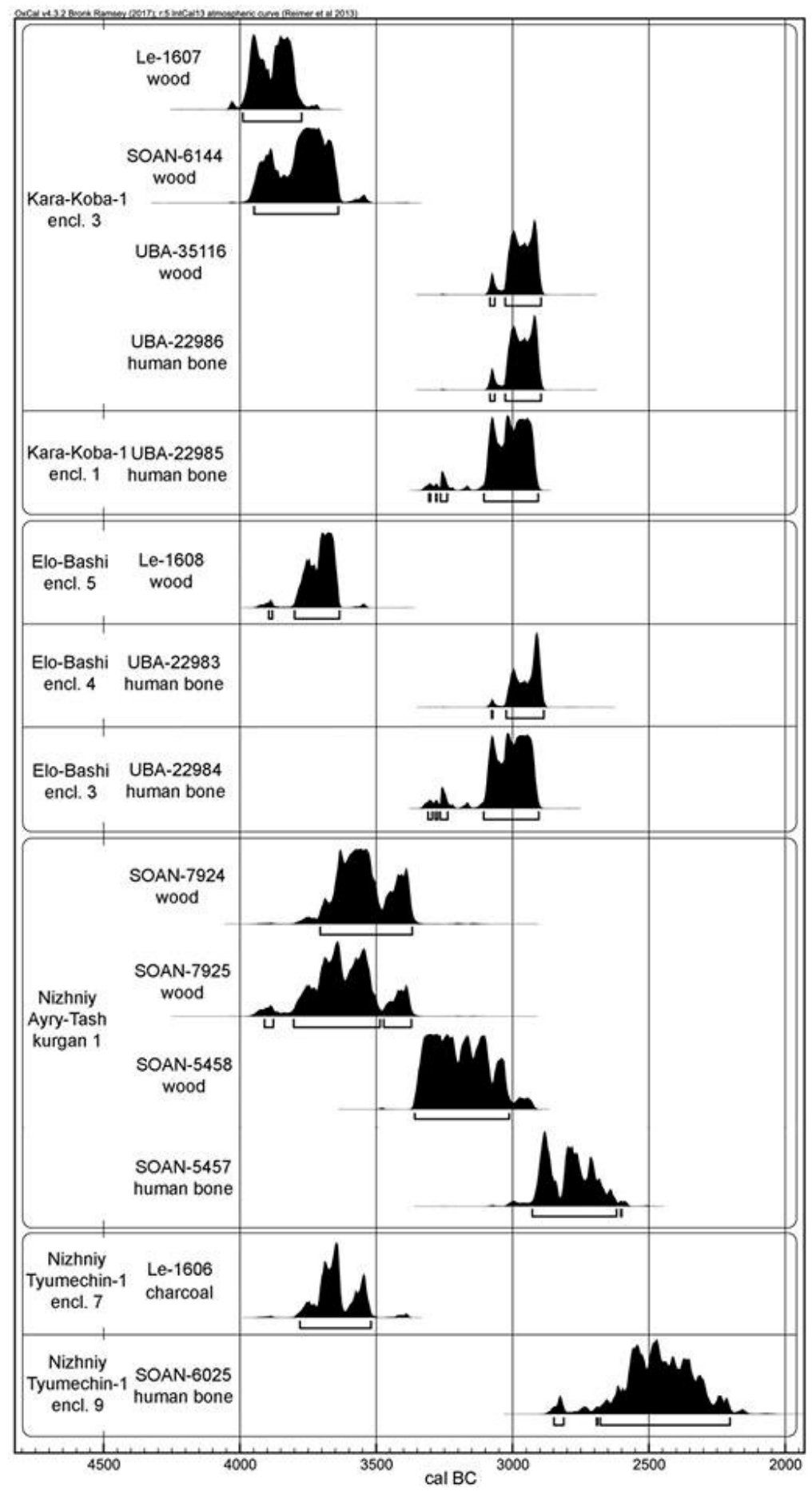

Fig. 2. Comparison of calibrated ${ }^{14} \mathrm{C}$ dates for wood/charcoal and human bone samples from the same Afanasyevo cemeteries in Altai

Two measurements from the wood samples from the Kara-Koba-1 cemetery (Le-1607 and SOAN-6144) made in different laboratories, however, produced almost identical results. This suggests that such an old date is not an analytical error. The trend towards the $250-600{ }^{14} \mathrm{C}$ years older dates from wood/charcoal samples is evident for virtually all analyzed sites of the Altai where the LSC method was used. This apparently systematic effect requires further investigation. The summed probability of wood dates is older than that from bone samples (Fig. 3). 


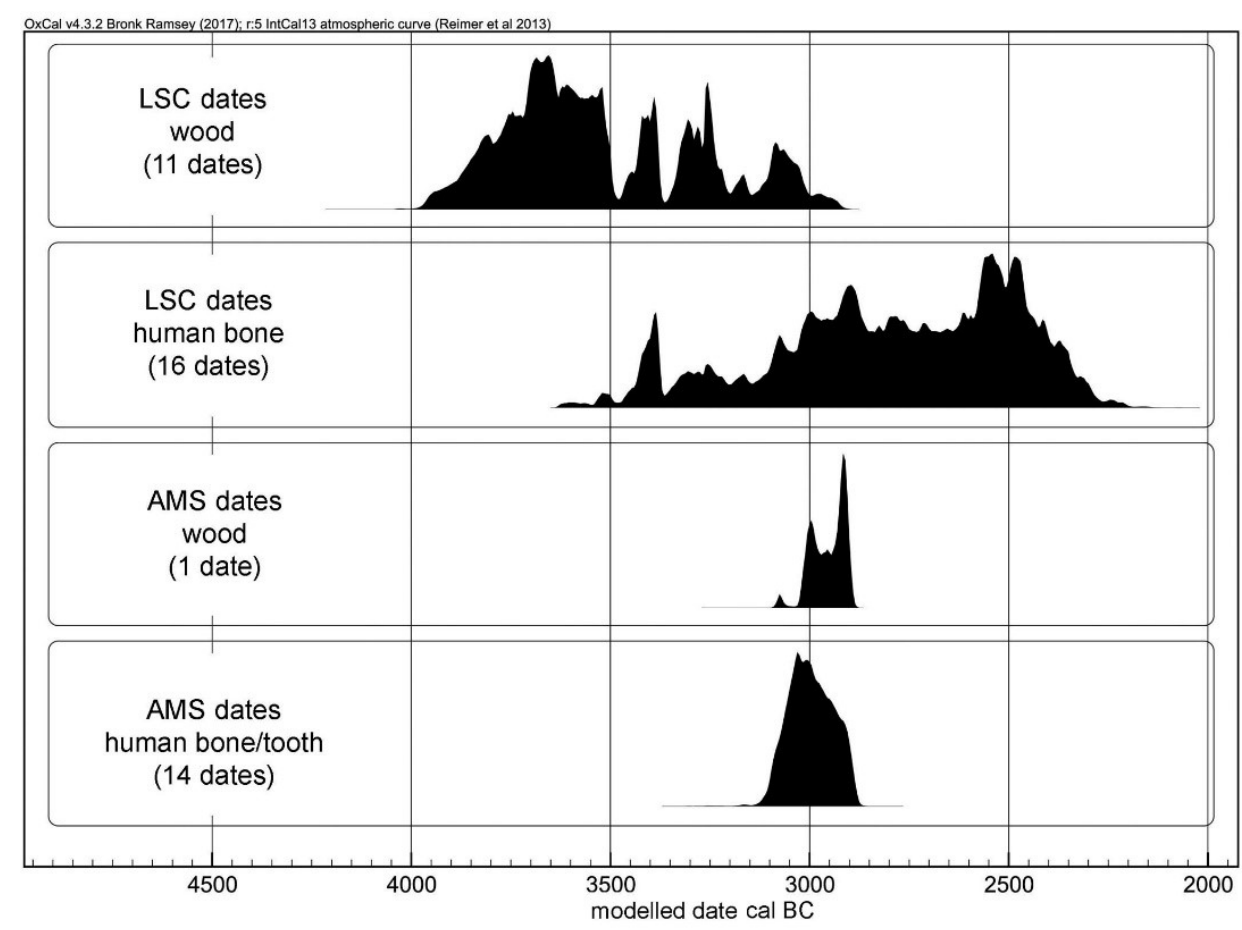

Fig. 3. Calibrated summed probability for the Afanasyevo cemeteries of the Altai by sample type and method

The factors leading to older dates from wood/charcoal samples are well known. Firstly, is the sampling of the central part of the tree trunk. The preservation of wooden structures in burials rarely allows sampling external rings that actually date the moment of cutting of the tree. Usually only the central part, that carries information about the initial period of the growth of the tree, is preserved. However, for the construction of burial ceilings, Siberian larch (Lárix sibírica) trunks about $30-40 \mathrm{~cm}$ in diameter were used. This species is fast-growing and its age with such a diameter should not exceed 50 years. Therefore, the chronological shift that occurs when using the central part of the logs should not be more than 50 years.

Secondly, the potential old-wood effect must be taken into account when the sampled tree was cut down in advance or re-used. For example, for the construction of burials, a no-longerneeded structure could be dismantled and reused. Larch timber is characterized by high density and is rather resistant to rotting. However, its strength properties are not unlimited and do not last for centuries. Thus, the re-use of older logs cannot be the cause of such large discrepancies, especially because wooden structures have not been recorded before the arrival of the Afanasyevo population in the Minusinsk Basin and the Altai.

One of the explanations for the up to 600-year older dates from wooden constructions may be related to the following feature of Siberian larch. Like oak, it improves its strength when steeped in water, becoming stronger and significantly more resistant to decay. Steeping usually occurs naturally when the tree falls into the water - as larch has a dense, heavy wood, it sinks. It is possible that Afanasyevo mound builders used larch from rivers or from old river beds, as well as collected logs washed out on the shore for construction. Another source of old wood could be trees killed by frost. This phenomenon is common, for example, in the valley of the Ursul River, where the cemetery of Kara-Koba-1 is located. Possibly such trees were more "available" to the Afanasyevo people. In general, based on a number of reasons, the radiocarbon dates from wood may actually be several hundred years older than the time of construction of a kurgan.

However, the problem of the older dates from wood samples, produced by the LSC method, is much wider. As it has already been mentioned, the only AMS date available at present from wood - from the Kara-Koba-1 cemetery - did not show the older age and appeared synchronous to 
the bone sample. This result raises even more questions. Perhaps, the reasons for the older dates are not only related to material itself but also to the analytical method or laboratory used.

\section{Middle Yenisei Region sites}

For the Minusinsk Basin sites, measurements on wood and charcoal samples $(n=27)$ prevail significantly. Only eight AMS and four LSC dates have been produced from human bone and tooth samples. Unlike in the Altai, the majority of dates from wood here are similar to those from bones/teeth (Fig. 4). The only site, where the dates can be suspected to be too old is the aforementioned Malinovy Log (Bokovenko \& Mityayev 2010; Polyakov 2010). Four dates from wood from the roofs of two adjacent mounds demonstrate an amazing clustering. But there is about a 600years gap between them and the rest of the dates from other burial grounds. This is another important evidence for the non-randomness and consistency of the phenomenon. The modern model of the development of the Afanasyevo Culture in the Middle Yenisei attributes this cemetery to the late period (Lazaretov 2017a, 2017b). In this case, the discrepancy with the real date of burial can reach about 800 years.

Only one attempt to radiocarbon date various materials from the same Afanasyevo burial has been made in the Middle Yenisei, for the Itkol II cemetery kurgan 23 grave 2. This attempt has not been very productive, as the age range for human bone appears too wide (Fig. 7 in Polyakov 2010). However, based on the dates of the Afanasyevo sites in the Altai, we can now assume that a number of dates from wood samples of the Minusinsk burial grounds can also be too old (such as Malinovy Log site). At the same time, analysing the entire assemblage of dates, it may be observed that, as opposed to the Altai, some of them (Le-931, Bln-4769, Bln-4919) are located on the top of the chronological range and cannot be too old. Apparently, while in the Altai the older dates from wood samples are a systematic phenomenon, in the Middle Yenisei this happens only sporadically.

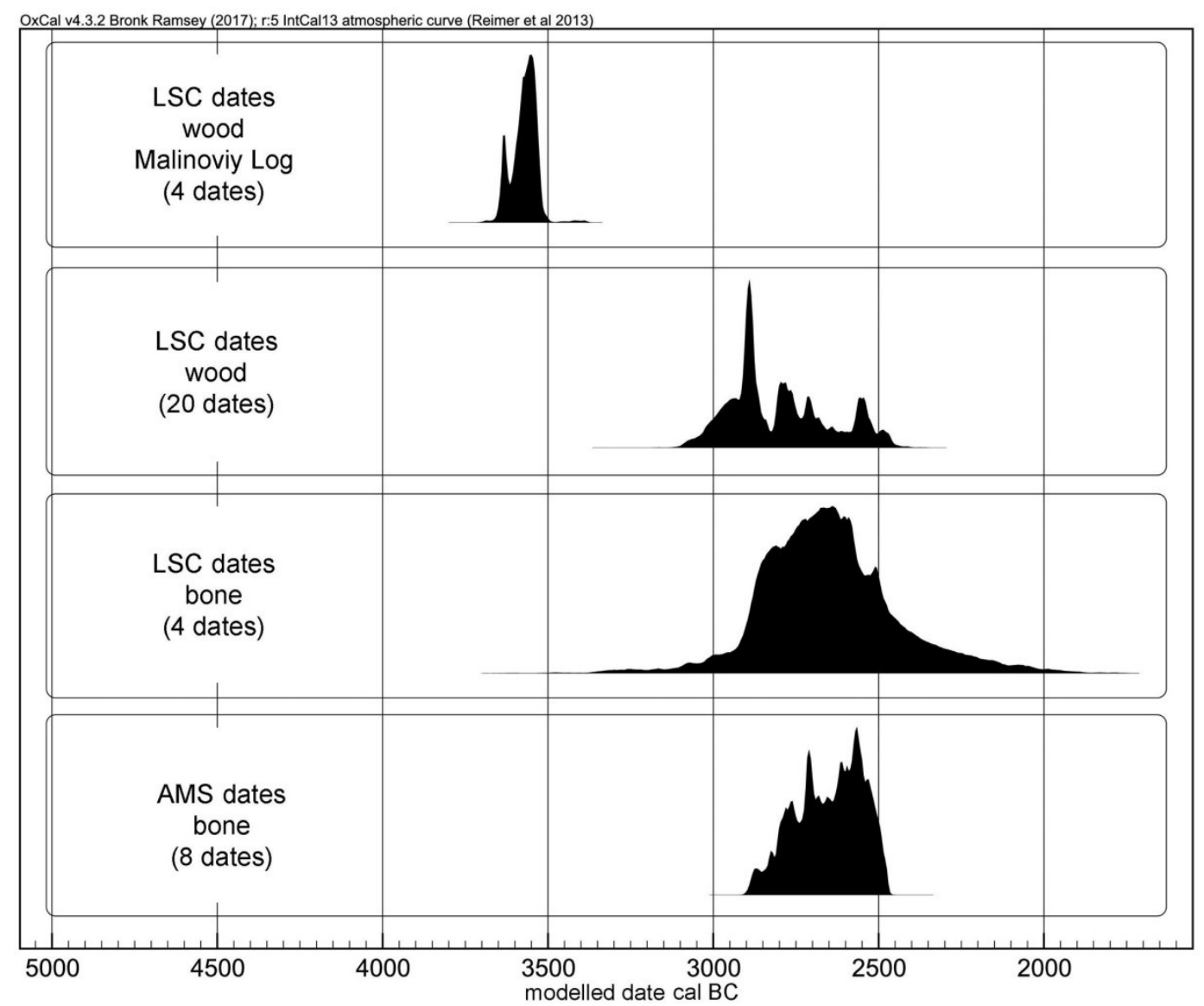

Fig. 4. Summed probabilities of calibrated ${ }^{14} \mathrm{C}$ dates for the Afanasyevo cemeteries in the Middle Yenisei by sample type and method 


\section{$\underline{\text { AMS vs LSC dates }}$}

The appearance of AMS dates brought up another important issue. For the human bone samples, the dates produced by the beta counting method often have extremely wide confidence intervals. They can range from 70 to 200 years, and after calibration the interval spans for more than 1000 years (Le-8913: 4270 \pm 200 BP or 3505-2342 cal BC, see Fig. 3). Besides, there are notable discrepancies between the results from the samples of the same burials produced in different LSC laboratories. For example, differences in the median of ${ }^{14} \mathrm{C}$ years between laboratories of IHMC RAS and the Institute of Archaeology and Ethnography of SB RAS reached 550 for Tytkesken VI kurgan 95 and 500 for Bersjukta I kurgan 1 (Fig. 8 in Polyakov 2010). Such a discrepancy appears only for human bone samples; no differences have been detected for the wood samples.

As such, at the moment AMS age ranges are the most "narrow". Fourteen AMS dates obtained for eight Afanasyevo cemeteries all fall within the narrow period of $31^{\text {st }}-29^{\text {th }} \mathrm{c}$. BC. At the same time, 16 LSC dates for human bones from ten cemeteries cover a period of more than 1000 years $-34^{\text {th }}-24^{\text {th }} \mathrm{c}$. BC. Despite quite a similar number of determinations, the resulting difference in range is more than three times. For the Middle Yenisei Region, the pattern is not as obvious because of the smaller number of measurements.

\section{$\underline{\text { Altai vs Minusinsk Basin summed probabilities for AMS }{ }^{14} \mathrm{C} \text { dates }}$}

An amazing pattern appears when comparing AMS ${ }^{14} \mathrm{C}$ dates for the Altai and Minusinsk Basin regions - the summed probabilities hardly overlap (Fig. 5). The summed probability dates are $31^{\text {st }}-$ start of $29^{\text {th }} \mathrm{c}$. BC for the Altai sites, and $29^{\text {th }}-$ start of $25^{\text {th }} \mathrm{c}$. BC for the Middle Yenisei (Minusinsk Basin).

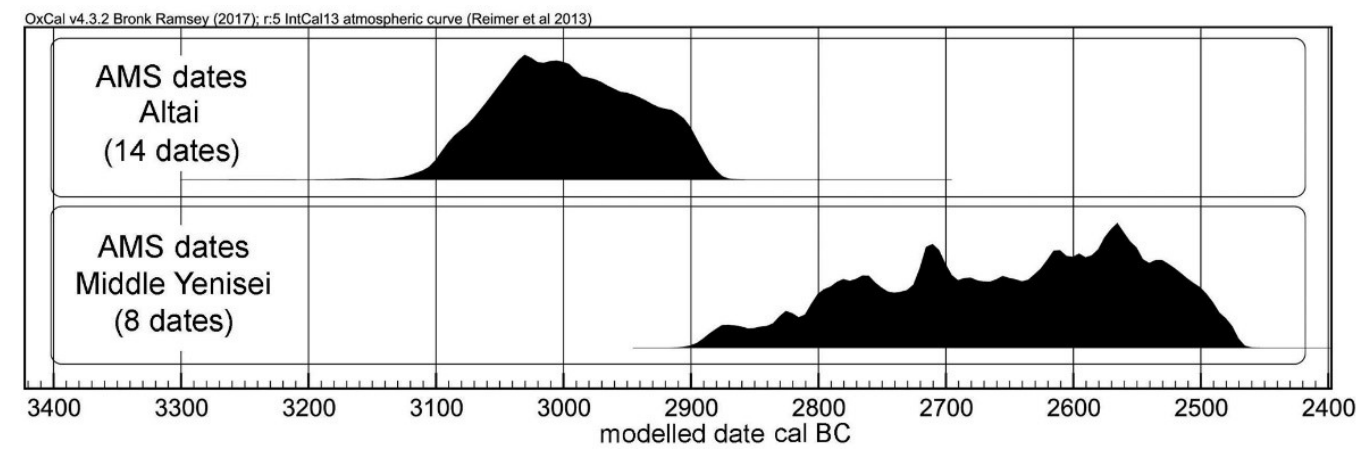

Fig. 5. Comparison of summed probabilities of calibrated ${ }^{14} \mathrm{C}$ dates for the Afanasyevo sites from different regions

However, we should not immediately conclude that the Afanasyevo population from the Altai moved to the Middle Yenisei Region, especially since there is no archaeological evidence for this (Stepanova 2010a). All eight measurements made for the Minusinsk sites have been received from only two typologically close sites of Afanasieva Gora and Karasuk III, which is not enough to represent the full spectrum of the Afanasyevo funerary monuments for this territory. Possibly, over time, the lower chronological boundary for the Minusinsk sites will be extended and early monuments will partly synchronize with the Altai ones. The main conclusion to be made at present is that ${ }^{14} \mathrm{C}$ dating confirms the relatively younger age of the Altai sites.

\section{$\underline{\text { Settlement vs burial dates (Altai sites) }}$}

To date, the ${ }^{14} \mathrm{C}$ measurements for settlement of the Afanasyevo Culture have only been done for the Altai Region, as there is not a sufficient number of settlements analyzed in the Middle Yenisei Region. Because of the large number of secondary factors that can affect the provenance of such samples (frost cracks, activity of burrowing animals, mixing of the layers while excavating middens etc.), especially in multilayer sites, these data should be assessed carefully, especially 
given that completely different samples, wood, charcoal, soil, animal bone were analysed. At the moment there are $14{ }^{14} \mathrm{C}$ dates from five Altai settlements available, of which only two are AMS.

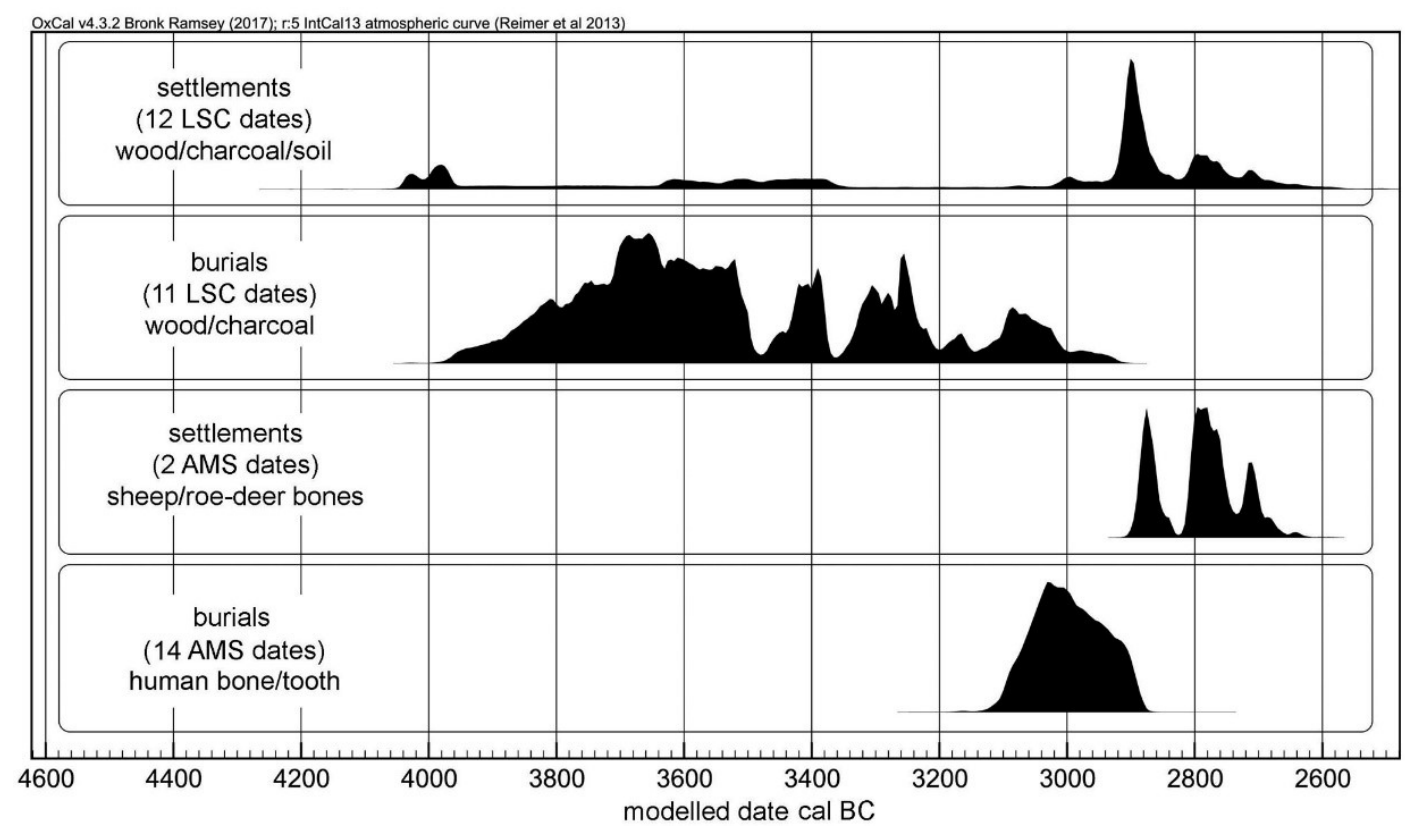

Fig. 6. Summed probabilities of calibrated ${ }^{14} \mathrm{C}$ dates for the Altai settlements and cemeteries

Comparison of the summed probabilities of the 14 settlement dates (LSC and AMS) with 14 AMS dates from cemeteries (the latter are all obtained from bones) demonstrates an interesting pattern (Fig. 6). Two settlement AMS dates (from herbivore bones), and the majority of the LSC dates (wood, charcoal, bone) are a bit younger than burial dates. Only four out of twelve LSC dates for settlements (SOAN-2744, SOAN-2742, SOAN-2844, SOAN-3802, obtained from, soil, charcoal and wood samples), are outliers and appear much older; they fall outside of standard deviation in statistical analysis. It is yet difficult to explain this phenomenon. One can only point out that a similar picture appears for other Bronze Age archaeological cultures of this region (Fig. 1 in Polyakov and Svyatko 2010).

\section{Relative Chronology}

In order to understand how the overall picture of the Altai and Middle Yenisei Bronze Age can change after the proposed adjustments to the chronology of the Afanasyevo Culture, we need to involve data from other cultures and individual types of sites.

\section{$\underline{\text { Altai sites }}$}

Until the formation of the Afanasyevo Culture, the Altai Mountains were inhabited by Neolithic tribes and, apparently, the population of the Bolshoy Mys Culture attributed to the Eneolithic period (Kiryushin 1986). Both settlement layers and cemeteries have been explored. Radiocarbon measurements of various samples from these sites set the Neolithic dates mainly to the $5^{\text {th }}$ $-4^{\text {th }}$ mil. BC (Kiryushin et al. 1995; Table 4 in Kungurova 2005; Kiryushin \& Kiryushin, 2008; Kiryushin 2015). These dates are much older and do not overlap with the chronological boundaries of the Afanasyevo Culture (Kiryushin 2015). So far, there are no reliable materials to explore interaction between local Neolithic groups and bearers of the Afanasyevo tradition. Thus, changing the lower chronological boundary of the Afanasyevo Culture does not create new contradictions.

In recent years, new types of sites with distinctive characteristics have been separated within the Afanasyevo Culture (Stepanova 2010b, 2012). Among them, the so-called Aragol and Ulita type sites have not yet been ${ }^{14} \mathrm{C}$ dated and cannot be chronologically compared with the other Afanasyevo sites. Yet, a relatively large series of eight LSC dates has been published for the sites 
of the so-called Kurota type. Comparison with other Afanasyevo dates demonstrates their synchroneity (Fig. 7), which also agrees with the archaeological materials.

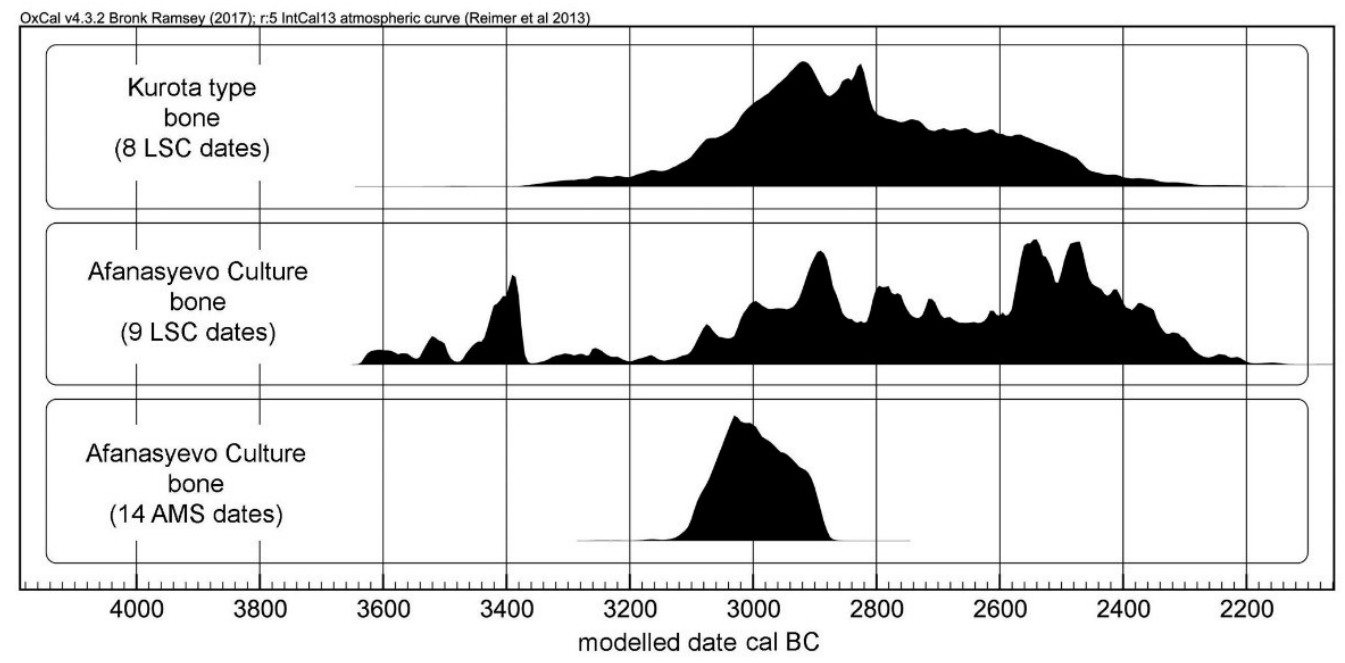

Fig. 7. Summed probabilities for the Afanasyevo Culture and Kurota type sites

According to the current model, in the Altai Mountains the Afanasyevo was replaced by the Karakol and Elunino cultures. The chronology of the latter is relatively well understood. Based on 34 measurements, it has been dated to the $27^{\text {th }}-17^{\text {th }}$ c. BC (Kiryushin et al. 2009). This agrees well with new AMS data for the chronology of the Afanasyevo Culture. The boundary between the two cultures lies at the turn of the $28^{\text {th }}-27^{\text {th }} \mathrm{c}$. BC. Much less chronological data has been obtained for the recently identified Karakol Culture - only five dates (one from a charcoal sample, and four from bones) have been produced for the Ozernoye cemetery. Importantly, a situation similar to one for the Afanasyevo Culture can be observed - the LSC date from charcoal is more than 1000 years older than AMS and LSC dates from bones (Fig. 8). That is to say that the effect of the older dates from wood/charcoal samples affects not only Afanasyevo, but also the Karakol Culture. Based on the remaining four dates, it should be attributed to the $25^{\text {th }}-24^{\text {th }} \mathrm{c}$. BC. These data are very preliminary, as only one burial ground has been dated; however, it does not contradict the revised Afanasyevo chronology (Fig. 9).

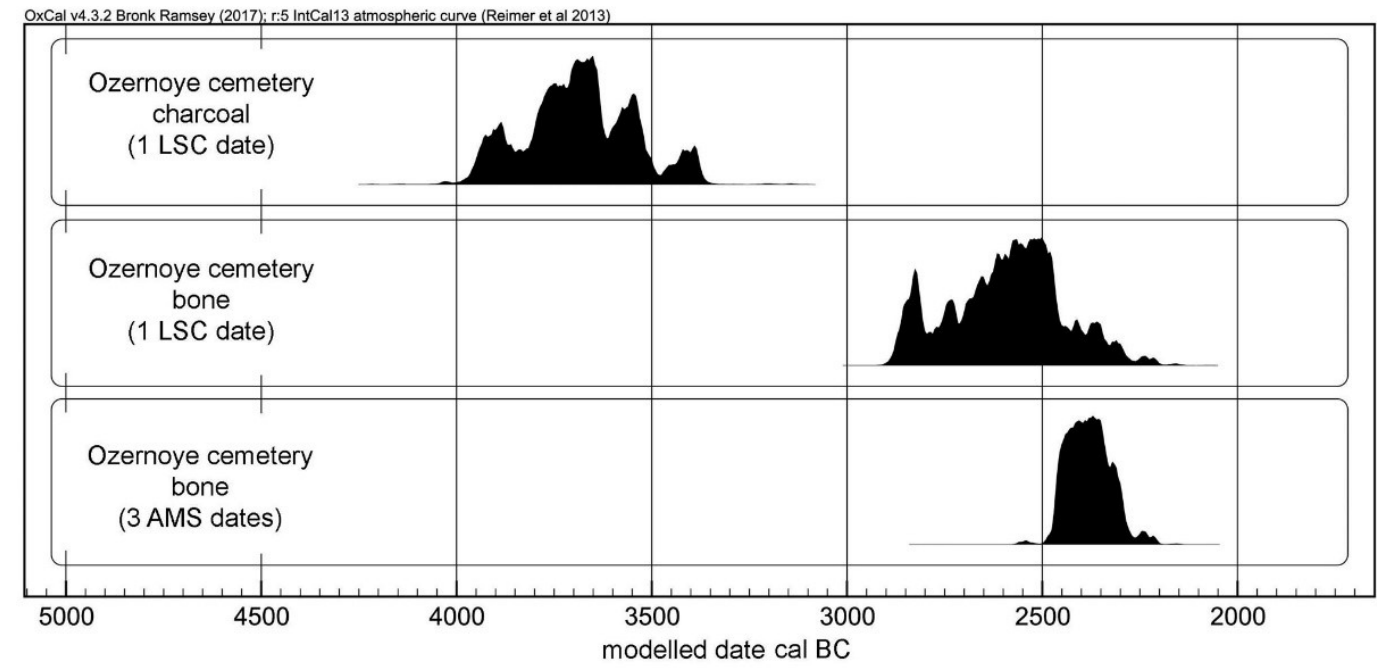

Fig. 8. Summed probabilities of the ${ }^{14} \mathrm{C}$ dates of the Ozernoye cemetery (Karakol Culture) by sample type and methods 


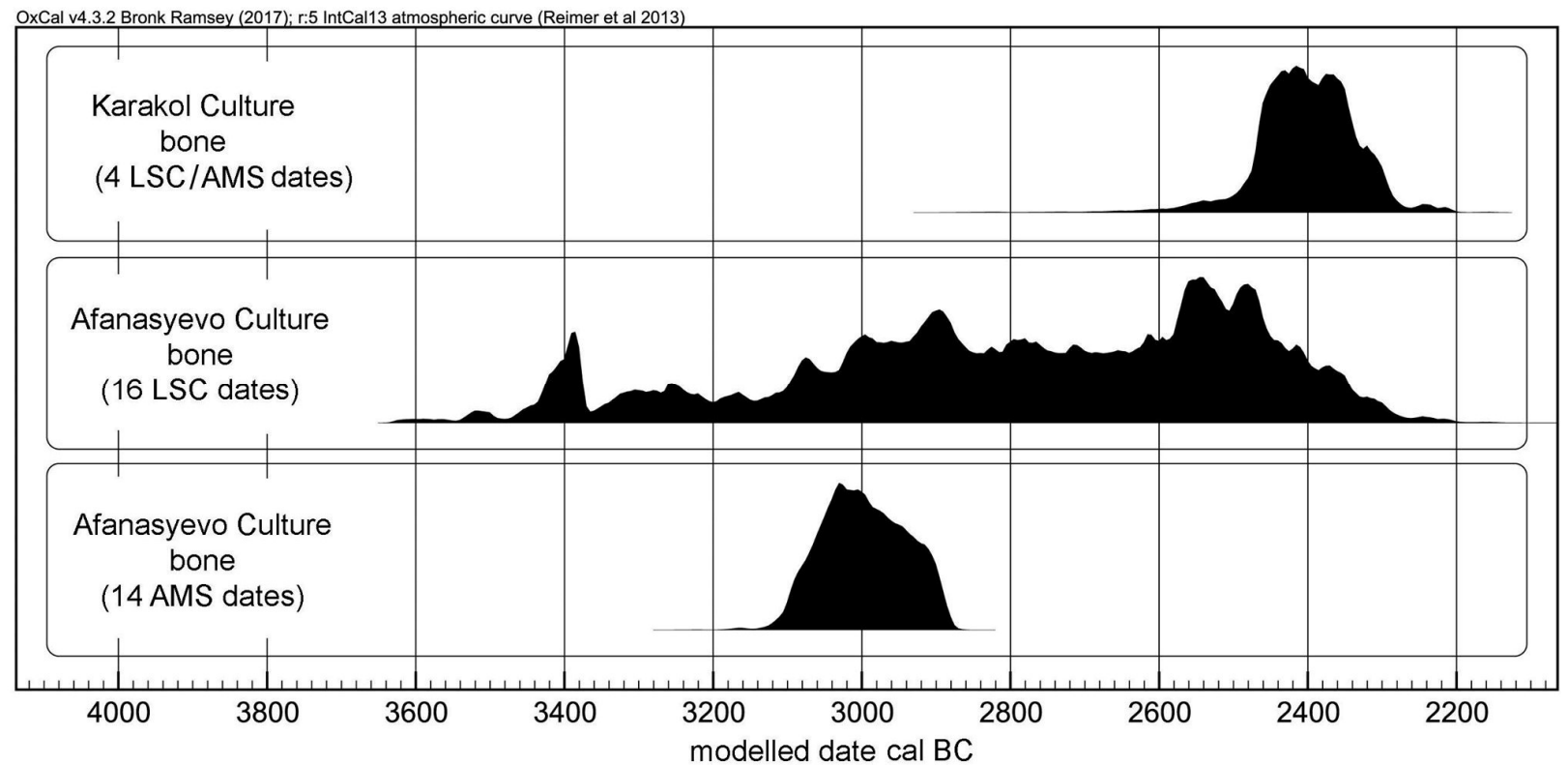

Fig. 9. Summed probabilities of the ${ }^{14} \mathrm{C}$ dates for the Afanasyevo and Karakol Cultures

\section{Minusinsk Basin sites}

In the Middle Yenisei region, the situation appears simpler. Before the emergence of the Afanasyevo Culture, this territory was inhabited by Neolithic tribes whose material culture has still been barely investigated (Vadetskaya 1986). As of today, there are no materials suitable for absolute dating. Therefore, the shift of the lower chronological boundary for the Afanasyevo Culture has no effect on the established timeframe. The upper chronological boundary of the Afanasyevo sites in the Middle Yenisei Region corresponds with the appearance of the Okunevo Culture, and its beginning was previously attributed to the $25^{\text {th }}$ c. BC (Svyatko at al. 2009; Polyakov \& Svyatko 2009). The new AMS data do not affect it. Only worth noting are slightly older early dates for Okunevo sites which belong to the $26^{\text {th }} \mathrm{c}$. BC. In this regard, it is appropriate to clarify here that currently the chronological boundary between the Afanasyevo and Okunevo Cultures is considered to fall in the $26^{\text {th }}-25^{\text {th }} \mathrm{c}$. BC, and that the period of their coexistence does not exceed 100 years (Polyakov 2017).

\section{Mongolian sites}

The only presently dated site of the Afanasyevo Culture in Mongolia is Kurgak-Govi 1. A series of LSC measurements from wooden structures, charcoal and human bones date it to the $29^{\text {th }}$ $26^{\text {th }}$ c. BC (Tables 1 and 3 in Kovalev \& Erdenebaatar 2010). No AMS dates are available for this region. The earlier Neolithic population in the area has been barely studied and has no known ${ }^{14} \mathrm{C}$ dates. Relatively later sites are represented by the recently identified Qiemuerqieke (Chemurchek) Culture (Kovalyev 2012). As of now, tens of sites have already been discovered and the issues similar to the ones revealed in this research have been encountered for them. Specifically, the series of dates obtained from the charcoal and wood samples from the ceilings of burials (first half of the $3^{\text {rd }}$ mil. BC) consistently appear to be older than the dates from human bone samples (second half of the $3^{\text {rd }}$ - beginning of the $2^{\text {nd }}$ mil. BC; Kovalev et al. 2008). Most of the new studies relate the materials of the Qiemuerqieke Culture to the second half of the $3^{\text {rd }}$ to beginning of the $2^{\text {nd }}$ mil. $\mathrm{BC}$. There is an expanding research database that demonstrates the affinity of this culture to the Okunevo and Elunino sites which date to the same time (Kiryushin et al. 2009; Kovalev 2012; Lazaretov 2017b; Polyakov 2017).

It can be ascertained that the newly proposed refined chronology of the Afanasyevo sites is consistent with the established views on the periodisation of the Paleometal period sites of Southern and Western Siberia. In general, our results suggest that the chronology of the 
Afanasyevo Culture was possibly not the same in different parts of the region. The oldest sites are located in the Altai Mountains, where the sites were apparently abandoned earlier than in other regions. In the Middle Yenisei region, the Afanasyevo sites probably appeared slightly later, yet the Afanasyevo population could have remained longer in that area. Perhaps the latter situation also happened in the Mongolian Altai, where some sites are ${ }^{14} \mathrm{C}$ dated to the $29^{\text {th }}-26^{\text {th }} \mathrm{c}$. BC.

\section{Conclusions}

The presented research was aimed to amalgamate and study in detail the entire existing body of ${ }^{14} \mathrm{C}$ data for the Afanasyevo Culture and their correlation with the traditional chronology. The previous "long" chronology of the Afanasyevo Culture was widely criticised and contradicted many observations and conclusions made in the course of extensive archaeological excavations. The detection of the exceedingly wide ranges of the LSC dates from bone samples produced in the laboratories of SB RAS and IHMC RAS, as well as the systematic shift of the data towards an older age for the wood and charcoal samples, finally reveal the shortcomings of the conventional "long" chronology.

Summarising the research, the following observations can be made:

1. From the AMS data (all from bone samples), the burials of the Afanasyevo Culture of Altai can be dated to the $31^{\text {st }}-29^{\text {th }} \mathrm{c}$. BC, whereas those of the Middle Yenisei Region to the $29^{\text {th }}-25^{\text {th }} \mathrm{c}$. BC. As the source database continues to grow, the chronological margins may broaden, i.e., be expanded or corrected.

2. This "narrower" chronology of the Afanasyevo Culture confirms the relatively earlier age of the Altai monuments, as compared to those of the Middle Yenisei Region.

3. Concerning the Altai burials, the LSC dates obtained from the wood samples appear to be systematically older by 250-600 years than the dates from human bone, and this was the reason of the unexplainable extension of the chronology of the Afanasyevo Culture in the area by 1400 years. A similar effect can be suggested in respect to particular Middle Yenisei sites (e.g. Malinoviy Log). The exact origins of this effect are still obscure. The only dated Afanasyevo site in Mongolia (Kurgak Govi-1) does not demonstrate any differences in ${ }^{14} \mathrm{C}$ dates from wood and human bone.

4. The new AMS data for the Afanasyevo burials of Altai appeared to be significantly better clustered $\left(31^{\text {st }}-29^{\text {th }} \mathrm{c}\right.$. BC) and in a good agreement with the accepted archaeological view of the short-term existence of the Afanasyevo Culture, as compared to the previous LSC results $\left(35^{\text {th }}-24^{\text {th }}\right.$ c. BC). The new data suggest revision of the conventional "long" chronology of the Afanasyevo Culture, which was the result of very broad confidence intervals of the previous dates and their great scatter, and inconsistency between the results from different laboratories for samples from the same grave, up to the absence of overlap in the obtained dates. A short chronology of the culture removes the contradictions with the archaeological data, explains the small number of sites, the small size of the cemeteries and the lack of the internal periodization. It also removes the inconsistency with the dating of the Yamnaya Culture which previously appeared "younger" than the Afanasyevo Culture. For the Middle Yenisei sites, the issue is not as evident. If we do not take into account dates from wood, the differences between the AMS and LSC dates from human bone are minimal. Perhaps this is due to the very small number of dates received so far.

5. The existing ${ }^{14} \mathrm{C}$ dates for the Altai settlements exhibit a very large scatter. However, when subjected to statistical screening, they fall in the chronological range of $29^{\text {th }}-28^{\text {th }} \mathrm{c}$. BC and appear younger than the main body of the AMS dates for the burials. The "younger" ${ }^{14} \mathrm{C}$ dates for settlements (as compared to funeral sites) have been also reported for other archaeological cultures of the region. Further investigations are required to clarify the origins of the phenomenon. 
Taking into consideration the whole body of data, we can clearly move towards a different perception. While earlier it was obvious that the Afanasyevo chronology was too broad and possible narrowing was expected, the current situation is the opposite. The new AMS dates only represent a "core" for the Afanasyevo chronology, which cannot be narrowed down. Potentially, in the future, the earlier and later sites will be AMS dated and the chronological borders for the culture will slightly expand over time. Even though, the changes will likely be insignificant and will primarily concern the materials from the Altai.

\section{Acknowledgements}

The study was supported by the Russian State Academies of Sciences program for basic research grants 0184-2018-0009 ("Interaction of the Ancient Cultures of North Eurasia and Eastern Civilisations in the Paleometal Period ( $4^{\text {th }}-1^{\text {st }}$ millennia BC)") and 0329-2018-0003 ("Historical-Cultural processes in Siberia and surrounding territories"). We are grateful the reviewers for the very useful comments on the manuscript of this paper.

\section{References}

Abdulganeev MT, Kiryushin YuF, Kadikov BH. 1982. Materialy epohi bronzy iz Gornogo Altaya [Bronze Age materials from the Altai Mountains]. In: Kiryushin YuF, ed. Arheologiya $i$ etnografiya Altaya. Barnaul: Altai State University Press. p. 52-77. In Russian.

Allentoft ME, Sikora M, Sjogren KG, Rasmussen S, Rasmussen M, et al. 2015. Population genomics of Bronze Age Eurasia. Nature 522(7555), 167-172.

Anthony DW. 2007. The Horse, the Wheel, and Language: How Bronze-age Riders from the Eurasian Steppes Shaped the Modern World. Princeton.

Avanesova NA. 2012. Svyatilishe rannih nomadov Zeravshana [Sanctuary of the early nomads of Zeravshan]. In: Stepanova NF, Polyakov AV, Vadetskaya EB, eds. Afanasyevskii Sbornik 2. Barnaul: Azbuka. p. 8-27.

Bazhenov AI, Borodaev VB, Maloletko AM. 2002. Vladimirovka na Altae - drevneishiy medniy rudnik Sibiri [Vladimirovka of Altai - the oldest copper mine of Siberia]. Tomsk. $119 \mathrm{p}$.

Bokovenko NA, Legran S. 2010. Mogilnik Numykhmar na reke Bidzha [Cemetery of Numykhmar on Bidzha River]. In: Stepanova NF, Polyakov AV, Tur SS, Shulga PI, eds. Afanasyevskii Sbornik. Barnaul: Azbuka. p. 29-35. In Russian.

Bokovenko NA, Mityaev PE. 2010. Afanas'evskii mogil'nik Malinovyi Log na Enisee [Afanasyevo cemetery of Malinoviy Log on Yenisei]. In: Stepanova NF, Polyakov AV, Tur SS, Shulga PI, eds. Afanasyevskii Sbornik. Barnaul: Azbuka. p. 16-29. In Russian.

Bronk Ramsey C. 2009. Bayesian analysis of radiocarbon dates. Radiocarbon 51(1), 337360.

Derevyanko AP, Molodin VI. 1994. Denisova peshzhera [Denisova cave]. Part 1. Novosibirsk: Nauka. 261 p. In Russian.

Dergachev VA. 1986. Moldaviya $i$ sosednie territorii v epohu bronzy [Moldavia and neighbouring territories in the Bronze Age]. Kishinev: Shtiinca. 220 p. In Russian.

Ermolova NM, Markov YN. 1983. Datirovanie arheologicheskih obrazcov iz mogilnikov epohi bronzy Yuzhnoi Sibiri [Dating of archaeological samples from the Iron Age cemeteries of Southern Siberia]. In: Masson VM (ed.). Drevnie kultury Evraziiskih stepei. Leningrad: Nauka. P. 95-98. In Russian. 
Fisenko VA. 1970. Plemena yamnoi kul'tury Yugo-Vostoka [Tribes of the Yamnaya Culture in South-East]. Saratov: Saratov University Press. 48 p. In Russian.

Görsdorf J, Parzinger H, Nagler A, Leontyev N. 1998. Neue ${ }^{14} \mathrm{C}$-Datierungen für die Sibirische Steppe und ihre Konsequenzen für die regionale Bronzezeitchronologie. Eurasia Antiqua 4: 73-80. 553-560.

Görsdorf J. 2002: Datierungsergebnisse des Berlinen ${ }^{14} \mathrm{C}$-Labors 2001. Eurasia Antiqua 8:

Görsdorf J. 2004. Datierungsergebnisse des Berlinen ${ }^{14} \mathrm{C}$-Labors 2003. Eurasia Antiqua 10: 401-409.

Grushin AP. 2009. Radiouglerodnaya hronologiya afanasyevskih pamyatnikov Gornogo Altaya [Radiocarbon chronology of the Afanasyevo sites in the Altai Mountains]. In: Kiryushin YuF, Tishkin AA (eds.). Rol' estestvenno-nauchnyh metodov $v$ arheologicheskih issledovaniyah. Barnaul: Izd-vo AGU. p. 110-112. In Russian.

Gryaznov MP. 1999. Afanasyevskaya kultura na Yenisee [The Afanasyevo Culture on Yenisey]. Saint-Petersburg: Dmitriy Bulanin. 136 p. In Russian.

Hlobystina MD. 1975. Drevneishie mogil'niki Gornogo Altaya [Ancient cemeteries of the Altai Mountains]. Sovetskaya Arheologiya 1: 17-33. In Russian.

Khokhlov AA, Solodovnikov KN, Rykun MP, Kravchenko GG, Kitov EP. 2016. Kraniologicheskie dannye $\mathrm{k}$ probleme svyazi populyacii yamnoi i afanas'evskoi kul'tur Evrazii nachal'nogo etapa bronzovogo veka [Craniological data on the problem of relation of the Yamnaya and Afanasyevo Culture populations of Eurasia in the early stage of the Bronze Age]. Vestnik arheologii, antropologii i etnografii 3(34): 86-106. In Russian.

Kiryushin YuF. 1986. Eneolit, rannyaya i razvitaya bronza Verhnego I Srednego Priobya [Eneolithic, Early and Developed Bronze Age of the Upper and Middle Ob River Region]. Dr Sci dissertation abstract. Novosibirsk. 35 p. In Russian.

Kiryushin KYu. 2015. Morphology and Decoration of Ceramics from Novoilyinka III-A Chalcolithic Settlement in Northern Kulunda, Southwestern Siberia. Archaeology, Ethnology \& Anthropology of Eurasia 43(1): 25-36.

Kiryushin KYu, Kiryushin YuF. 2008. Kulturno-hronologicheskiye kompleksy poseleniya Tytkesken-2 (itogi rabot 1988-1994 gg.) [Cultural-chronological complexes of the Tytkesken-2 settlement (the results of the work in 1988-1994). Barnaul: Altai State University Press. 33 p. In Russian.

Kiryushin YuF, Papin DV. 2010. Nekotorye voprosy radiouglerodnoi hronologii pamyatnikov andronvskoi kul'tury Altaya [Some questions of radiocarbon chronology of the Andronovo Culture sites in Altai]. In: Molodin VI (ed). Arheologicheskie izyskaniya v Zapadnoi Sibiri: proshloe, nastoyashee, budushee. Novosibirsk: Izd-vo NGPU. p.19-21. In Russian.

Kiryushin YuF, Stepanova NF. 2004. Skifskaya epoha Altaya. Ch.III. Pogrebal'nye kompleksy skifskogo vremeni Srednei Katuni [Scythian period of Altai. P. III. Funeral complexes of Scythian time of Central Katun]. Barnaul: Altai State University Press. 292 p. In Russian.

Kiryushin YuF, Posrednikov VA, Firsov LV. 1981. Absolyutnyi vozrast nekotoryh pamyatnikov neolita i bronzy Zapadnoi Sibiri [Absolute age of some Neolithic and Bronze Age sites of Western Siberia]. In: Troitskaya TN (ed.). Problemy Zapadno-Sibirskoi arheologii. Epoha kamnya i bronzy. Novosibirsk: Nauka. p. 28-32. In Russian.

Kiryushin YuF, Kungurov AL, Stepanova NF. 1995. Arheologiya Nizhnetytkeskenskoi pezhshery 1 [Archaeology of the Nizhniy Tytkesken cave 1]. Barnaul: Altai State University Press. 151 p. In Russian. 
Kiryushin YuF, Grushin SP, Papin DV. 2009. Radiouglerodnaya hronologiya pamyatnikov epohi rannego metalla Altaya [Radiocarbon chronology of the early metal sites of Altai]. In: Kiryushin YuF, Tishkin AA (eds.). Rol' estestvenno-nauchnyh metodov v arheologicheskih issledovaniyah. Barnaul: Altai State University. p. 120-124. In Russian.

Kiryushin YuF, Papin DV, Fedoruk OA. 2015. Andronovskaya kul'tura na Altae (po materialam pogrebal'nyh kompleksov) [Andronovo Culture in Altai (on materials from funeral complexes)]. Barnaul: Altai State University. 108 s. In Russian.

Kiselev SV. 1938. Sovetskaya arheologiya Sibiri perioda metalla [Soviet archaeology of the metal period in Siberia]. Vestnik Drevney Istorii 1(2): 228-243. In Russian.

Kovalev AA. 2012. Chemurchekskii kul'turnyi fenomen: istoriya izucheniya, datirovka, proishozhdenie [Qiemuerqieke cultural phenomenon: history of research, dating, origins]. In: Kovalev AA (ed.). Chemurchekskii kul'turnyi fenomen. Issledovaniya poslednih let. SPb.: p. 32-55. In Russian.

Kovalev AA, Erdenebaatar D. 2010. Afanas'evsko-chemurchekskaya kurgannaya gruppa Kurgak-govi (Huurai Gov') i voprosy vneshnih svyazei afanas'evskoi kul'tury [AfanasyevoQiemuerqieke kurgan group in Kurgak-govi (Huuray Gov') and questions of external relations of the Afanasyevo Culture]. In: Stepanova NF, Polyakov AV, Tur SS, Shulga PI, eds. Afanasyevskii Sbornik. Barnaul: Azbuka. p. 91-108. In Russian.

Kovalev AA, Erdenebaatar D, Zaitseva GI, Burova ND. 2008. Radiouglerodnoe datirovanie kurganov Mongol'skogo Altaya, issledovannyh Mezhdunarodnoi Central'noaziatskoi arheologicheskoi ekspediciei, i ego znachenie dlya i tipologicheskogo uporyadochivaniya pamyatnikov bronzovogo veka Central'noi Azii [Radiocarbon dating of the barrows of the Mongolian Altai investigated by the International Central Asian archaeological expedition, and its value for typological ordering of the Bronze Age sites in Central Asia]. In: Tishkin AA (ed.). Drevnie $i$ srednevekovye kochevniki Central'noi Azii. Barnaul: Azbuka. p. 172-189. In Russian.

Kovaleva IF. 1984. Sever Stepnogo Podneprov'ya v eneolite - bronzovom veke [North of Dnieper Steppe Region in the Eneolithic - Bronze Age]. Dnepropetrovsk: Dnepropetrovsk State University. 115 p. In Russian.

Kungurova NYu. 2005. Mogil'nik Soloncy-5. Kul'tura pogrebennyh neolita Altaya [Cemetery of Soloncy-5. Neolithic funeral culture in Altai]. Barnaul: Barnaul Law Institute of the Ministry of Internal Affairs of Russia. 128 p. In Russian.

Kuzmina E. 2007. The Origin of the Indo-Iranians. Leiden-Boston: Brill Academic Publishers. Edited by J. Mallory.

Kuzminyh SV. 1993. Kvazieneoliticheskie kul'tury Severnoi Evrazii: problema periodizacii [Kvasieneolithic cultures of North Eurasua: the problem of periodization]. In: Borzunov VA, Vasiliev IB (eds.). Arheologicheskie kul'tury I kul'turno-istoricheskie obshnosti Bol'shogo Urala. Ekaterinburg. p. 116-119. In Russian.

Lazaretov IP. 2017a. K otnositelnoi hronologii Afanasievskoi Kultury Srednego Eniseya ili horosho zabytoye staroye [To the relative chronology of the Afanasyevo culture of the Middle Yenisei or long forgotten old]. Drevnosti Sibiri i Centralnoi Azii 8(20): 8-34. In Russian.

Lazaretov IP. 2017b. Obshnost' kul'tur Sayano-Altaya v epohu rannei bronzy [The unity of the Sayano-Altai cultures in the Early Bronze Age]. In: Derevyanko AP, Tishkin AA (eds.). V (XXI) Vserossiiskii arheologicheskii s'ezd: sbornik nauchnyh trudov. Barnaul: Altai State University. p. 277-282. In Russian.

Lanting JN, J van der Plicht. 1998. Reservoir effect and apparent 14C ages. The Journal of Irish Archaeology 9: 151-165. 
Maksimenkov GA. 1965. Vpusknye mogily okunevskogo etapa v afanasyevskih kurganah [Intrusive burials of the Okunevo stage in the Afanasyevo kurgans. Sovetskaya arheologiya 4: 204-211. In Russian.

Mallory JP. 1989. In Search of the Indo-Europeans. London: Thames and Hudson.

Mallory JP, VH Mair. 2000. The Tarim Mummies: The Mystery of the First Westerners in Ancient China. London and New York: Thames and Hudson.

Marsadolov LS. 1985. Hronologiya kurganov Altaya (VIII-IVvv. do n. e.) [Chronology of barrows in Altai $\left(8^{\text {th }}-4^{\text {th }}\right.$ c. BC)]. PhD thesis abstract. Leningrad. p. 1-16. In Russian.

Merpert NYa. 1974. Drevneishie skotovody Volzhsko-Ural'skogo mezhdurech'ya [The most ancient cattle-farmers of the Volga-Ural Interfluve]. Moscow: Nauka. 167 p. In Russian.

Molodin VI. 2002. Gornyi Altai v epohu bronzy [Altai Mountains in the Bronze Age]. In: Derevyanko AP, ed. Istoriya respubliki Altai. T.1. Drevnost' i srednevekov'e. Gorno-Altaisk: Institute of Altai Studies n.a. S.S. Surazakov. p.97-142. In Russian.

Molodin VI, Alkin SV. 2012. Pamyatniki afanas'evskogo vremeni na severo-zapade Kitaya (Sin'czyan) [Monuments of the Afanasyevo time in the northwest of China (Xinjiang)] In: Stepanova NF, Polyakov AV, Vadetskaya EB, eds. Afanasyevskii Sbornik 2. Barnaul: Azbuka. p. 149154. In Russian.

Morgunova NL, Kravcov AYu. 1994. Pamyatniki drevneyamnoi kul'tury na Ileke [Sites of the Yamnaya Culture on Ilek]. Ekaterinburg: Nauka. 153 p. In Russian.

Orlova LA. 1995. Radiouglerodnoe datirovanie arheologicheskih pamyatnikov Sibiri i Dal'nego Vostoka [Radiocarbon dating of archaeological monuments of Siberia and the Far East]. In: Derevyanko AP, ed. Metody estestvennyh nauk v arheologicheskih rekonstrukciyah. P. 2. Novosibirsk: Institute of Archaeology and Ethnography of the Siberian Branch of the Russian Academy of Sceinces. p. 205-233. In Russian.

Pogozheva AP. 2006. Afanas'evskaya kul'tura [Afanasyevo Culture]. In: Molodin VI (ed.). Epoha eneolita i bronzy Gornogo Altaya. P. 1. Barnaul: Azbuka, p.18-48. In Russian.

Pogozheva AP, Rykun MP, Stepanova NF, Tur SS. 2006. Epoha eneolita I bronzy Gornogo Altaya [Eneolithic and Bronze Age of the Altai Mountains]. V. 1. Barnaul. 234 p. In Russian.

Polyakov AV. 2006. Periodizaciya "klassicheskogo" etapa karasukskoi kul'tury (p materialam pogrebal'nyh pamyatnikov) [Periodization of the "classic" phase of the Karasuk culture (from materials of funerary monuments)]. PhD dissertation theses. Saint-Petersburg. 26 p. In Russian.

Polyakov AV. 2010. Radiouglerodnye daty afanas'evskoi kul'tury [Radiocarbon dates of the Afanasyevo Culture]. In: Stepanova NF, Polyakov AV, Tur SS, Shulga PI, eds. Afanasyevskii Sbornik. Barnaul: Azbuka. p. 158-171. In Russian.

Polyakov AV. 2017. Radiouglerodnye daty okunevskoi kul'tury [Radiocarbon dates of the Okunevo Culture]. Zapiski IIMK RAN 16: 52-74. In Russian.

Polyakov AV, Svyatko SV. 2009. Radiouglerodnoe datirovanie arheologicheskih pamyatnikov neolita - nachala zheleznogo veka Srednego Eniseya: obzor rezul'tatov i novye dannye [Radiocarbon dating of archaeological monuments of the Neolithic - Early Iron Age of the Middle Yenisei: Review of the results and new data]. Teoriya i praktika arheologicheskih issledovanii 5: 20-56. In Russian.

Rasmussen S, Allentoft Morten E, Nielsen K, Orlando L, Sikora M, Sjögren K-G, et al. 2015. Early Divergent Strains of Yersinia pestis in Eurasia 5,000 Years Ago. Cell 163(3): 571582. 
Reimer PJ, Bard E, Bayliss A, Beck JW, Blackwell PG, Bronk Ramsey C, Buck CE, Cheng H, Edwards RL, Friedrich M, Grootes PM, Guilderson TP, Haflidason H, Hajdas I, Hatté C, Heaton TJ, Hoffmann DL, Hogg AG, Hughen KA, Kaiser KF, Kromer B, Manning SW, Niu M, Reimer RW, Richards DA, Scott EM, Southon JR, Staff RA, Turney CSM, van der Plicht J (2013) IntCal13 and Marine13 Radiocarbon Age Calibration Curves 0-50,000 Years cal BP. Radiocarbon 55: $1869-1887$.

Savinov DG. 1994. Mogil'nik Bertek-33 [Cemetery of Bertek-33]. In: Molodin VA, Dereviyanko AP (eds.). Drevnie kul'tury Bertekskoi doliny. Novosibirsk: Nauka. p.39-49. In Russian.

Scott EM, Cook GT, Harkness DD, Miller BF, Baxter MS. 1992. Further Analysis of the International Intercomparison Study (Ics). Radiocarbon 34(3):520-7.

Scott EM, Cook GT, Naysmith P. 2010a. A Report on Phase 2 of the Fifth International Radiocarbon Intercomparison (VIRI). Radiocarbon 52(3): 846-858.

Scott EM, Cook GT, Naysmith P. 2010b. The Fifth International Radiocarbon Intercomparison (VIRI): An Assessment of Laboratory Performance in Stage 3. Radiocarbon 52(2-3): 859865.

Shaposhnikova OG, Fomenko VN, Dovzhenko ND. 1986. Yamnaya kul'turno-istoricheskaya oblast' (yuzhnobugskii variant) [Yamnaya cultural-historical oblast (south Bug type)]. In: Rybakov BA (ed.). Svod arheologicheskih istochnikov. V. 1-3. Kiev:Naukova Dumka. 160 p. In Russian.

Sementsov AA, Romanova EN, Doluhanov PM. 1969. Radiouglerodnye daty laboratorii LOIA [Radiocarbon dates of the LOIA laboratory]. Sovetskaya Arheologiya 1: 251-261. In Russian.

Slyusarenko Yu. 2010. Dendrohronologicheskoe datirovanie arheologicheskih pamyatnikov skifskoi epohi Altaya [Dendrochronological dating of the archaeological monuments of the Scythian era in Altai]. PhD thesis abstract. Novosibirsk. 34 p. In Russian.

Soenov VI, Akimova (Vdovina) TA, Triganova SV. 2012 Radiouglerodnye daty pogrebenii perioda rannei bronzy na mogil'nikah Nizhnii Airy-Tash I Ozernoe (Gornyi Altai) [Radiocarbon dates of the early Bronze Age burials at the cemeteries of Nizhnii Airy-Tash I and Ozernoe (Altai Mountains). In: Stepanova NF, Polyakov AV, Vadetskaya EB, eds. Afanasyevskii Sbornik 2. Barnaul: Azbuka. p. 166-172. In Russian.

Soenov VI, Trifanova SV. 2010. Pogrebeniye perioda ranney bronzy na Nizhnem Tarhate [The burial of the Early Bronze Age period on the Nizhniy Tarhat]. In: Stepanova NF, Polyakov AV, Tur SS, Shulga PI, eds. Afanasyevskii Sbornik. Barnaul: Azbuka. p.172-176. In Russian.

Stepanova NF. 2008. Predvaritel'nye itogi issledovanii ishodnogo syr'ya i formovochnyh mass keramiki neolita-bronzy Gornogo Altaya i ego predgorii [Preliminary results of the analysis of raw materials and forming mass of the Neolithic to Bronze Age pottery from the Altai Mountains and the foothills]. In: Soenov VI (ed.). Izuchenie istoriko-kul'turnogo naslediya narodov Yuzhnoi Sibiri. V. 7. Gorno-Altaisk: AKIN. p. 23-31. In Russian.

Stepanova NF. 2009. Problemy absolyutnoi i otnositel'noi hronologii pamyatnikov afanas'evskoi arheologicheskoi kul'tury Gornogo Altaya [Problems of the absolute and relative chronology of the Afanasyevo archaeological cultures sites in the Altai Mountains] In: YuF Kiryushin and AA Tishkin (resp. eds). Rol Estestvenno-Nauchnyh Metodov v Arheologicheskih Issledovaniyah. Barnaul: Altai State University Press. S.154-159. In Russian.

Stepanova NF. 2010a. Afanas'evskaya kul'tura Gornogo Altaya i Eniseya: pogrebal'nyi obryad i keramika (shodstvo i razlichiya) [Afanasyevo Culture of Altai and Yenisei: funerary rite 
and ceramics (similarities and differences]. In: Stepanova NF, Polyakov AV, Tur SS, Shulga PI, eds. Afanasyevskii Sbornik. Barnaul: Azbuka. p. 177-187. In Russian.

Stepanova NF. 2010b. Aragol'skii i ulitinskii tipy pogrebenii epohi bronzy (Gornyi Altai) [Aragol and Ulita types of burials in the Bronze Age (Altai Mountains)]. In: Hozyaistvennokul'turnye tradicii Altaya v epohu bronzy. Barnaul: Altai State University. p. 24-37. In Russian.

Stepanova NF. 2010c. Osobennosti ishodnogo syr'ya i formovochnyh mass keramiki epohi neolita i bronzy Gornogo Altaya i ego severnyh predgorii [Characteristics of the raw materials and moulding composition of the Neolithic and Bronze Age pottery of the Altai Mountains and their foothills]. In: Drevnee goncharstvo: itogi i perspektivy izucheniya. Moscow: Institute of Archaeology of the Russian Academy of Sciences. p. 117-125. In Russian.

Stepanova NF. 2012. Problemy hronologii afanas'evskoi kul'tury [Problems of chronology of the Afanasyevo Culture]. In: Stepanova NF, Polyakov AV, Vadetskaya EB, eds. Afanasyevskii Sbornik 2. Barnaul: Azbuka. p. 183-195.

Stepanova NF. 2015. Rol' keramiki v izuchenii afanas'evskoi kul'tury [The role of pottery for the study of the Afanasyevo Culture]. In: Tsetlyn YuB (ed.). Sovremennye podhody $k$ izucheniyu drevnei keramiki v arheologii. Moscow: IA RAN. p. 269-277. In Russian.

Surazakov AS. 1989. Gornyi Altai i ego severnye predgor'ya v epohu rannego zheleza. Problemy hronologii i kul'turnogo razgranicheniya [Altai Mountains and the northern foothills during the Early Iron Age. Problems of chronology and cultural differentiation]. Gorno-Altaisk: Altai book publisher: Gorno-Altaisk division, 214 p. In Russian.

Svyatko SV, Polyakov AV. 2009. Noviye radiouglerodniye daty pamyatnikov epohi bronzy - nachala zheleznogo veka Srednego Yeniseya [New radiocarbon dates of the Bronze Early Iron Age sites of the Middle Yenisey]. In: Yu. F. Kiryushin and A. A. Tishkin (resp. eds). Rol Estestvenno-Nauchnyh Metodovv Arheologicheskih Issledovaniyah. Barnaul: Altai State University Press. P. 146-149. In Russian.

Svyatko SV, Mallory JP, Murphy EM, Polyakov AV, Reimer PJ, Schulting RJ. 2009. New Radiocarbon Dates and a Review of the Chronology of Prehistoric Populations from the Minusinsk Basin, Southern Siberia, Russia. Radiocarbon 51(1): 243-273.

Svyatko S, Reimer P, Schulting R. 2017a. Modern Freshwater Reservoir Offsets in the Eurasian Steppe: Implications for Archaeology. Radiocarbon 59(5): 1597-1607.

Svyatko SV, Polyakov AV, Soenov VI, Stepanova NF, Reimer PJ, Ogle N, et al. 2017b. Stable isotope palaeodietary analysis of the Early Bronze Age Afanasyevo Culture in the Altai Mountains, Southern Siberia. Journal of Archaeological Science: Reports 14(Supplement C): $65-75$.

Svyatko SV, Schulting R, Poliakov A, Reimer PJ. 2017c. A lack of freshwater reservoir effects in human radiocarbon dates in the Eneolithic to Iron Age in the Minusinsk Basin. Archaeological and Anthropological Sciences 9(7): 1379-1388.

Tsyb SV. 1984. Afanas'evskaya kul'tura Altaya [Afanasyevo Culture of Altai]. PhD Thesis Abstract. Kemerovo. 19 p. In Russian.

Vadetskaya EB. 1981. Afanas'evskii mogil'nik Krasnyi Yar [Afanasyevo cemetery of Krasniy Yar]. In: Troitskaya TN (ed.). Problemy zapadnosibirskoi arheologii: epoha kamnya i bronzy. Novosibirsk: «Nauka» Sibirskoe otdelenie. p. 33-62. In Russian.

Vadetskaya EB. 1986. Arkheologicheskiye pamyatniki v stepyakh Srednego Yeniseya [Archaeological Sites in the Steppes of the Middle Yenisey]. Leningrad: Nauka.180 s. In Russian. 
Vadetskaya EB. 2010. Mogil'nik Chernova VI (Respublika Hakasiya) [Cemetery of Chrnovaya VI (Khakassia Respublic)]. In: Stepanova NF, Polyakov AV, Tur SS, Shulga PI, eds. Afanasyevskii Sbornik. Barnaul: Azbuka. p. 35-46. In Russian.

Vadetskaya EB. 2012. Mogil'nik Malye Kopeny II [Cemetery of Maliye Kopyony II]. In: Stepanova NF, Polyakov AV, Vadetskaya EB, eds. Afanasyevskii Sbornik 2. Barnaul: Azbuka. p. 85-102. In Russian.

Vadetskaya EB, Polyakov AV, Stepanova NF. 2014. Svod pamyatnikov afanas'evskoi kul'tury [Corpus of sites of the Afanasyevo Culture]. Barnaul: Azbuka. 380 p. In Russian.

Vdovina TA. 2004. Avariyniye raskopki na mogilnike Nizhniy Ayry-Tash [Emergency excavations on the Nizhniy Ayry-Tash cemetery]. Drevnosti Altaya 12: 6-12. In Russian.

Yarovoi EV. 1985. Drevneishie skotovodcheskie plemena Yugo-Zapada SSSR [The most ancient cattle-breeding tribes of the USSR south-west]. Kishinev: Shtiinca. 124 p. In Russian.

Yarovoi EV. 1990. Kurgany eneolita - epohi bronzy Nizhnego Podnestrov'ya [EneolithicBronze Age kurgans of the lower Dniester Region]. Kishinev: Shtiinca. 272 p. In Russian.

Zaitseva GI. 2007. Radiouglerodnaya gruppa IIMK RAN: istoriya sozdaniya, sovremennoe sostoyanie [Radiocarbon group of the IIMK RAS: origins, current state]. Zapiski IIMK: 93-141. In Russian.

Zaitseva GI, van Geel B. (2004) The Occupation History of the Southern Eurasis Steppe During the Holocene: Chronology, the Calibration Curve and Methodological Problems of the Scythian Chronology. In: Marian Scott E., Alekseev A.Y., Zaitseva G. (eds) Impact of the Environment on Human Migration in Eurasia. NATO Science Series: IV: Earth and Environmental Sciences, vol 42. Springer, Dordrecht

Zaitseva GI, Bokovenko NA, Alekseev AYu, Chugunov KV, Scott EM (eds.). 2005. Eurasia in the Scythian Time: radiocarbon and archaeological chronology. St.-Petersburg: Teza. 290 p. In Russian with English abstract. 